Division of Agriculiural sciences U N I VER I T Y OF CALIFORN IA

\title{
CONTROL OF FIELD RODENTS ON CALIFORNIA FARMS
}
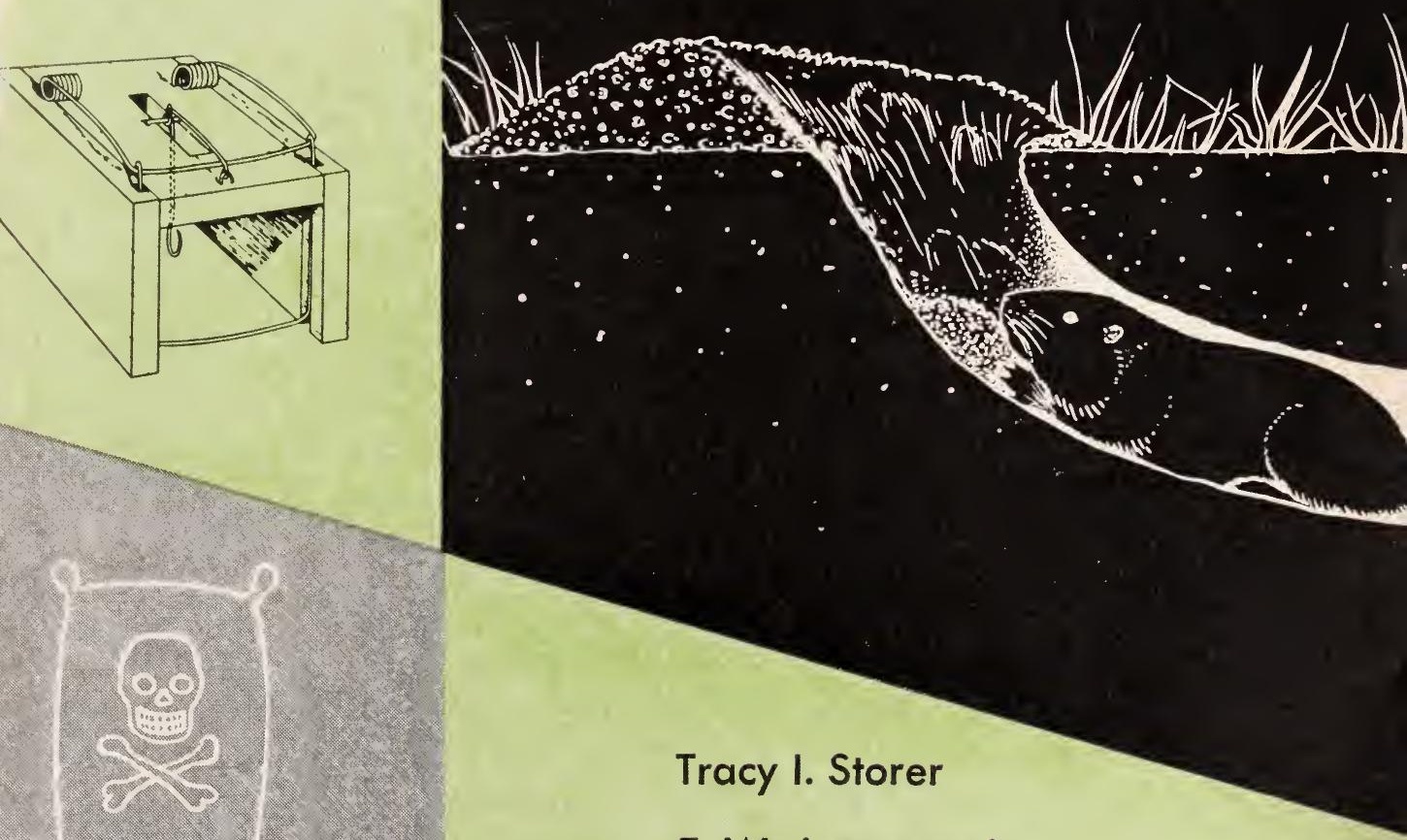

E. W. Jameson, Jr. 
Rodents can be controlled over large areas, but it is neither easy nor cheap to do so. On large farms it is difficult and sometimes impossible to eradicate field rodents, but persistent effort will keep them at a low level.

CONTROL O

This circular describes the different kinds of rodents found on California farms, and explains control methods of proved effectiveness.

THE AUTHORS: Tracy I. Storer is Professor of Zoology Emeritus, and Zoologist Emeritus in the Experiment

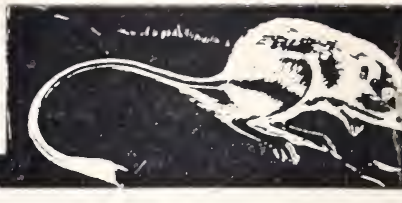
Station, Davis; E. W. Jameson, Jr., is Professor of Zoology and Zoologist in the Experiment Station, Davis.

JULY, 1965

This publication replaces Circular 434 .

\section{SOME GENERAL SUGGESTHONS}

Fields should be checked regularly and when rodents or evidence of their work is seen control methods should be employed promptly to prevent a build-up of the population. As one County Agricultural Commissioner put it, "It is easier and cheaper to kill the first eight ground squirrels than to kill the last eight." If you already have a large number of rodents, be prepared to spend some time and money for control.

Consult your local University of California Farm Advisor and your County Agricultural Commissioner about rodent problems. Regulations on use of poisonous baits vary from one county to another, as do the rodent-control services offered by county agencies. In a few counties the commissioner's office will take over completely, and without charge, when a farmer reports trouble with ground squirrels. In most counties, however, services are more limited and all costs are borne by the landowner or tenant

When poison bait is needed, check with your local county agricultural commissioner's office first. This can save you expense and trouble, especially in preparation of poisoned baits, because specialists in these offices have the equipment and training to prepare baits economically and safely.

If your commissioner's office does not have prepared baits of the type you need, try a reliable farm supply organization. Cautions for the storage and use of dangerous material are printed on container labels. These directions must be followed with the utmost care.

When preparing poison baits on the farm, the utmost care should be exercised to protect people and farm animals from accidental poisoning. See pages 6 and 7 for precautions in handling poisons and baits. 


\section{FNELD RODENTS ON CALIFORNIA FARMS}

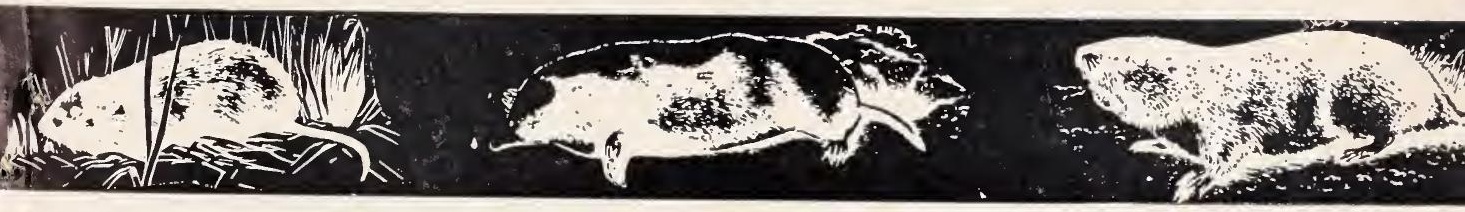

\section{RODENT DAMAGE, AND METHODS OF CONTROL}

\section{Economic Importance of Rodents}

The field rodents-pocket gophers, ground squirrels, tree squirrels, mice, kangaroo rats, muskrats, and rabbits ${ }^{2}-$ on farm lands are man's competitors, affecting his business, pleasure, and health.

Pockets gophers often injure or kill individual orchard trees and are an expensive nuisance in alfalfa and vegetable crops. Ground squirrels cause appreciable losses in cereal crops and reduce forage in pastures and on heavily grazed range lands. Ground squirrels, pocket gophers, brown rats, and especially muskrats damage ditchbanks and levees by burrowing. Jack rabbits and, less often, cottontails gnaw bark on trees and vines, and often reduce produce in truck and field crops and in home gardens. Control by farmers and by government officials on public lands will reduce such damage.

Total economic losses probably amount to several million dollars annually in California. Rodent control in California,

\footnotetext{
${ }^{1}$ The brown rat, and the house mouse, besides being household pests, also are field rodents in many places. See Ext. Leaf. 127. "How to Control Rats and Mice" for methods.
}

public and private, has cost at least one million dollars annually in some recent years when several million acres were treated.

A few of California's native rodents are beneficial, and many are neutral insofar as man's interests are concerned. Muskrats, tree squirrels, and cottontail rabbits, are useful as fur bearers or game animals to trappers or sportsmen, but they can be harmful to the farmer.

\section{Field Rodents and Disease}

Some rodents carry diseases transmissible to man. Plague in California was first detected in 1900 among rats. It was later found in ground squirrels and other rodents, and by 1946 plague has been found at one time or another in 37 counties. Transmitted chiefly by fleas, it is called "sylvatic plague" in rodents and "bubonic plague" in man. The more deadly form, known as "pneumonic plague," is spread from person to person by coughing (droplet infection); in two small epidemics of this type in California the mortality was above 90 per cent. Plague occurs mostly in rats, ground squirrels, deer mice, and field mice.

Tularemia, a disease first discovered 
in California, occurs in rabbits, ground squirrels, and various other rodents. Man may contract the disease while skinning infected animals, or, rarely, by eating improperly cooked rabbit flesh or drinking infected water. The disease may be transmitted by certain insects and by ticks. The reservoir for tularemia is in wild rodents, and occasionally in soil, mud, and standing water.

Rocky Mountain spotted fever, a serious and often fatal tick-borne disease, is present in Plumas, Lassen, Modoc, and eastern Siskiyou counties, and in states of the arid western interior. It is transmitted to man by bites of infected ticks from various mammals, especially rabbits. Relapsing fever, is present around Lake Tahoe, Big Bear Lake in the San Bernardino Mountains, and other mountain regions. Carried by small chipmunks, it may be transmitted to man by the bite of infected ticks.

Because squirrels and other rodents may be carriers of disease, capturing them as pets or handling live or dead individuals should be avoided.

The California Department of Public Health and the U. S. Public Health Service issue information circulars and technical reports on some rodent-borne diseases. The presence of sick or dying field rodents should be reported promptly to the local county agricultural commissioner, health officer, or the Department of Public Health.

Information on disease in wild rodents is available in a book by Hull (1955); see references on page 8 .

\section{Agencies dealing with Rodent Control}

The U. S. Fish and Wildlife Service supervises rodent control on federally owned lands and the California Department of Agriculture, advises on operations in the counties by the county agricultural commissioners. The U. S. Public Health Service studies rodent-borne dis- eases and conducts campaigns against rodents in and about seaports. The California Department of Public Health makes surveys of rodents to determine the presence of diseases transmissible to human beings. When infections are found, reports are sent to the State Department of Agriculture which then carries on necessary control operations (Calif. Agricultural Code, 1959, Sec. 139.5). County agricultural commissioners are responsible for rodent control in the counties, but responsibility for control on privately owned lands rests witl the individual, unless it is a matter of public health being in danger.

\section{Methods of Rodent Control}

There is no one easy method to control all kinds of rodents, but certain welltested methods will keep most species in check. For successful operations one must know the kind of rodent, its habits, food preferences, breeding season, and whether or not it hibernates. The farmer, however, must study the habits and occurrence of the rodents on his land, decide which method to use, and check on the results of each control operation.

The principal means of control are: poison baits and poisonous gases; trapping; shooting; exclusion; and encouragement of natural enemies.

\section{Poison Baits}

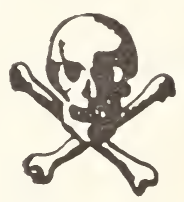

Control work with poison, even when supervised by official agencies, may also kill desirable animals-no control operation (except selective shooting) is without this hazard-but careful use of the more conservative methods will minimize the difficulty.

To prepare baits, foods that rodents like-grains, greens, pieces of vegetables or fruits-are poisoned and broadcast or placed in burrows or other protected 
spots. Such baits must not be exposed where they will be dangerous to livestock, beneficial wild life, or people.

Most county agricultural commissioners prepare and sell certain kinds of poison bait, and they sometimes have clean oat groats for making groundsquirrel bait; if not, they can provide the names of reliable commercial brands. For most small applications it is more economical to purchase prepared baits. Several counties have one or more special rodent inspectors to direct control measures or apply them, but in most counties the landowner or tenant pays for materials and either provides or pays for the labor.

Both the poison and bait must be suitable for the kind of rodent to be controlled.

Strychnine is the chief poison used for pocket gophers, jack rabbits, and kangaroo rats, and formerly was much used for ground squirrels.

Zinc phosphate is useful in control of ground squirrels, meadow mice, and muskrats. Phosphorus and arsenical compounds, formerly used widely, are no longer recommended.

The anticoagulants-warfarin, Pival $®$, Fumarin $®$, etc.-when eaten for several days destroy the ability of the blood to clot and the animal dies of hemorrhage. These chemicals are commonly used to control domestic rats and mice and may be used safely and effectively for control of ground squirrels about homes, farm headquarters, and summer camps-and for meadow mice, muskrats, and pocket gophers in some places.

Commercia! preparations of poisoned baits are on sale under various brand or trademarked names.

Any poison or poisoned bait to be offered for sale in California must first be submitted to the State Department of Agriculture, and only those which are satisfactory are licensed for sale (Agric. Code, 1959, Secs. 1061-1080.9). Poisons and poisoned baits sold in interstate com- merce must also meet the requirements of the Federal Insecticide, Fungicide, and Rodenticide Act of June 25, 1947. The name and the percentages of the active ingredients, together with proper warnings concerning the poison used, must be printed on the label of each product.

Two other rodent poisons, thallium sulfate and Compound 1080, are not available for use by the general public because of the far greater hazards they involve. Baits poisoned with these chemicals bear no indications of their poisonous nature in appearance, taste, or odor. Both are poisonous to rodents, other wild animals, domestic livestock, and man.

Thallium sulfate (thallous sulfate, $\mathrm{Tl}_{2} \mathrm{SO}_{4}$ ) has been used by government agencies for both rats and field rodents. On several occasions grain treated with this poison was mistakenly used for human food; several people became ill and some died.

Compound 1080 (sodium fluoroacetate) has been used in certain places for rodent control since 1945 by government agencies. It is extremely poisonous for all kinds of animals, and there is great danger that dogs and cats may be poisoned by eating rodents killed by it. It has also caused human deaths.

State law restricts sale or possession of these two poisons in California to federal, state, county, and municipal officers and to licensed structural pest-control operators (California Agricultural Code, 1959, Sec. 1080.5, 1080.6). There is no certain antidote for either poison. Thallium sulfate is slow-acting, but 1080 works so rapidly that it usually has been impossible to save experimental animals even with prompt and proper attention.

\section{Poisonous Gases}

Several poisonous gases available from dealers in garden supplies have served to control ground squirrels.

Carbon disulfide, although inflam. mable and explosive, has been used in 
large quantities. The gas is pumped into burrows, or balls of waste (jute) are soaked in fluid carbon disulfide and thrown into the burrows.

Methyl bromide has served for followup operations against ground squirrels. This gas has a decided advantage in plague-control work because it kills both squirrels and fleas (or other insects) in the burrows. It is extremely poisonous, and at least one human death has occurred through improper use in insect control. Methyl bromide is supplied as a fluid under pressure in heavy steel cylinders, or in 1-pound cans for smaller operations. Special applicators are necessary to distribute the gas; it is considered too costly for routine work.

Hydrocyanic acid gas is usually generated by placing calcium cyanide in flake or dust form in burrows containing some moisture. This is effective for rat control but unsatisfactory for ground squirrels because their burrows are too dry.

Sulfur dioxide, formerly employed for ground squirrel control, has been replaced by other gases.

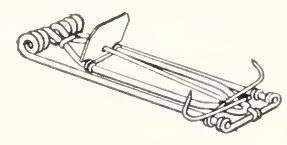

\section{Trapping, Shooting, and Exclusion}

Trapping is effective for control of pocket gophers and moles in gardens, and for field mice and wood rats in houses, and is often used for other species. Shooting will control small numbers of ground squirrels and rabbits. Exclusion, where practicable, is the best method because it may bring lasting results. It can be used to protect small plots or gardens against ground squirrels, pocket gophers, and rabbits. On a large scale it is expensive, and cannot be applied to all kinds of rodents or in all places.

\section{Encouragement of Natural Enemies}

Common rodents have natural enemies that help check their increase, and these predators are an asset to agriculture. The badger, red-tailed hawk, barn owl, and gopher snake are so useful that only a very shortsighted person would destroy them. The coyote feeds on rodents but also preys on domestic animals and birds, so its status depends on the viewpoint of the individual farmer. Whenever possible, farmers should protect owls, hawks, snakes, and other animals that prey on rodents. Killing of raptorial birds is prohibited by state law.

There is a popular belief that certain rodents may be killed by disease germs (virus) spread on baits. Bacterial cultures have been sold for this purpose, but the State Department of Public Healtl has made such sale illegal in California. These cultures are generally ineffective for rodent control, and sometimes they infect humans. Use of such bacteria (of the paratyphoid group (Salmonella) to control rats in hospitals has resulted in outbreaks of food poisoning among the human inmates. Thus, efforts to control rodents by spreading disease among them is illegal, impractical, and dangerous.

\section{GeNerAL PRECAUTIONS WITH POISONS}

All substances used for poisoning field rodents are dangerous to human beings and to domestic animals. Such substances should therefore be handled, stored, and labeled with great care, using the following precautions. 
1. Label all containers "POISON" and keep them locked up and out of reach of children, irresponsible adults, pets and livestock.

2. Wear an approved mask when mixing powdered or volatile poisons. If working outdoors, do not let the dust drift into watering troughs, irrigation ditches, or food-storage areas.

3. Mix poison baits, particularly those containing zinc phosphide, out of doors or in a well-ventilated building where there will be less hazard to the operator. Never mix poison in a room where animal or human food is prepared or stored.

4. A metal-topped table, or one that can be thoroughly washed, should be used for mixing. If necessary to use a wooden table, cover it with wrapping paper, oil cloth, or similar material which can be burned after the mixing operation is completed.

5. Wear rubber gloves when mixing and distributing poison baits, particularly those containing zinc phosphide. Burn gloves after using or wash them with detergent at some place where the wash water can drain onto soil that can be spaded in. Do not put gloves into garbage for disposal.

6. Wash hands carefully after mixing or handling baits, even though gloves have been worn.

7. Wash utensils thoroughly after mixing baits and pour out the rinse water where it will not be a hazard to people or animals. Utensils employed for mixing poisoned baits must not be used for any other purpose.

8. Always handle poisonous gases out of doors. Do not breathe the fumes. Stand up-wind when using or placing the material in burrows.

9. Store carbon disulfide in tightly-stoppered cans or drums in a cool dry place, out of doors or in a separate building, away from all fire, sparks, and matches. It is a dangerous gas and highly explosive. The drums should be grounded with a wire when filling cans or pump.

\section{HANDLE POISONS AS THOUGH YOUR LIFE DEPENDS ON IT. IT DOES!}

The minimum lethal dosage of strychnine for a human being is considered to be about 0.5 grain or 35 milligrams-equivalent to about 250 kernels of strychnine-coated grain. About 5 ounces of zinc phosphide bait may be fatal for a human being. Carbon disulfide is lethal in a concentration of about 1 part in 1,000 parts of air with 30 minutes exposure.

Antidotes for the different poisons vary, and some may be uncertain or not wholly effective in their action. In a case of accidental poisoning it is imperative that a physician be called immediately for most effective use of antidotes. 


\section{For more information ...}

Additional material about rodents is available in the following publications:

Eadie, W. R. 1954. Animal control in field, farm, and forest. viii +257 pp. The Macmillan Co., New York.

Hull, T. G.

1955. Diseases transmitted from animals to man. 4 th ed. $x x+717$ pp. Illus. C. C. Thomas, Springfield, Ill.

Ingles, L. G.

1954. Mammals of California and its coastal waters. Revised ed. Stanford University Press, Stanford University, Calif. xiii +396 pp. Illus.

Martin, A. C., H. S. Zim, and A. L. Nelson.

1951. American wildlife and plants. McGraw-Hill Book Co., New York. ix +500 pp. Illus.

Storer, T. I.

1960. Controlling rats and mice. California Agricultural Experiment Service Leaflet $127: 1: 28,15$ figs. 


\section{POCKET GOPHERS AND MOLES}

\section{These burrowing animals are harmful to agriculture in many parts of California}

The pocket gopher (Genus Thomomys; fig. 1) is a blunt-headed, stout-bodied, short-legged rodent which feeds on leaves. tender stems, and on some roots and bulbs. It has two pairs of exposed chisellike incisor teeth and, at either side of the mouth, an external fur-lined cheek pouch for carrying food. The fur is brownish above and grayish below, the eyes and ears are small, the tail is short and scantily haired, and the front toes have long slender claws. The head and body measure 6 to 8 inches and the tail is 3 to 4 inches long.

Pocket gophers and moles differ in appearance and structure (figs. 1 and 9); the mole has a tapered head, small teeth. large front feet with heavy claws, and velvety black fur. Differences in methods of work by the two are shown in figures 2 and 10.
Most of California is inhabited by pocket gophers. There are few in poor soils or where plant growth is sparse, but many in areas where herbage is abundant.

\section{Habits}

Burrows. The pocket gopher is an inhabitant of the soil, living in burrows of its own construction. never climbing, and only occasionally coming out on the surface. Its clean-cut cylindrical tunnels, averaging 2 to $2 \frac{1}{2}$ inches in diameter, are more or less parallel with the soil surface, mostly at depths of 6 to 14 inches (some are deeper). An entire burrow system may extend 50 to 100 feet or more.

In tunneling the gopher digs with its long fore claws, using its incisor teeth to cut roots or dislodge small stones. Loosened soil gathers under its body and is kicked backward loy the hind feet. When

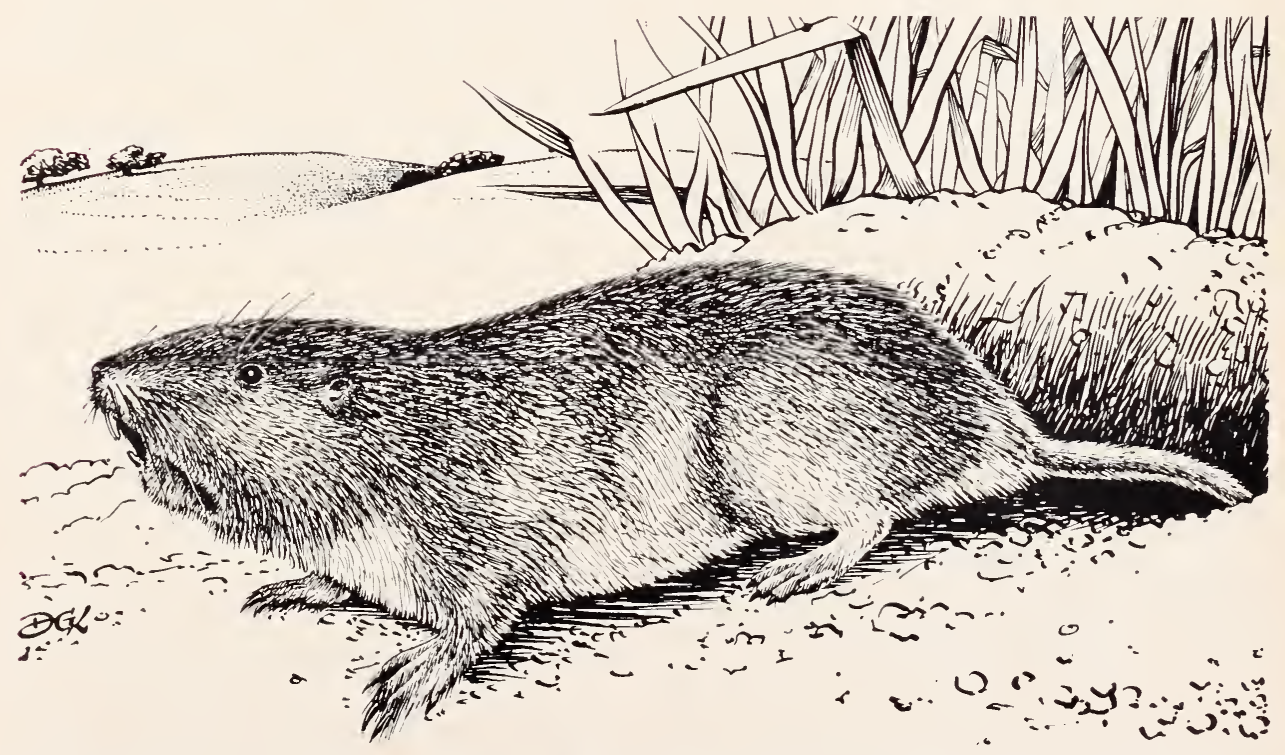

Fig. 1. Pocket gopher. Important features are the blunt head, small eyes and ears, fur-lined cheek pouch at each side of mouth, long slender claws on forefeet, and scantily haired tail. Head and body 6 to 8 inches, tail 3 to 4 inches. Compare with fig. 9 . 


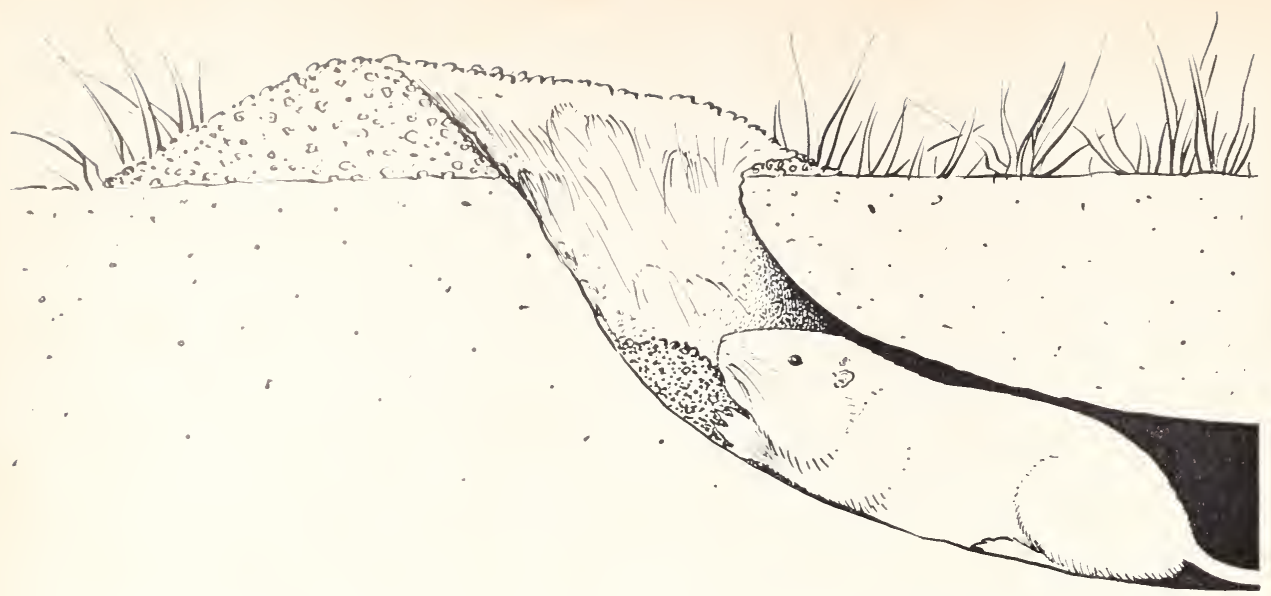

Fig. 2. Method of the pocket gopher in pushing earth out of a lateral tunnel, by use of the forefeet and head; later the exit will be closed with earth for some distance down the lateral tunnel. Compare with fig. 10.

enough soil has accumulated the animal turns about in place, brings the fore feet together under its chin, and pushes the loose dirt out on the surface through a short lateral off the main tunel (figs. 24). Successive loads result in a low rounded mound somewhat crescentshaped (soil is sometimes also packed in

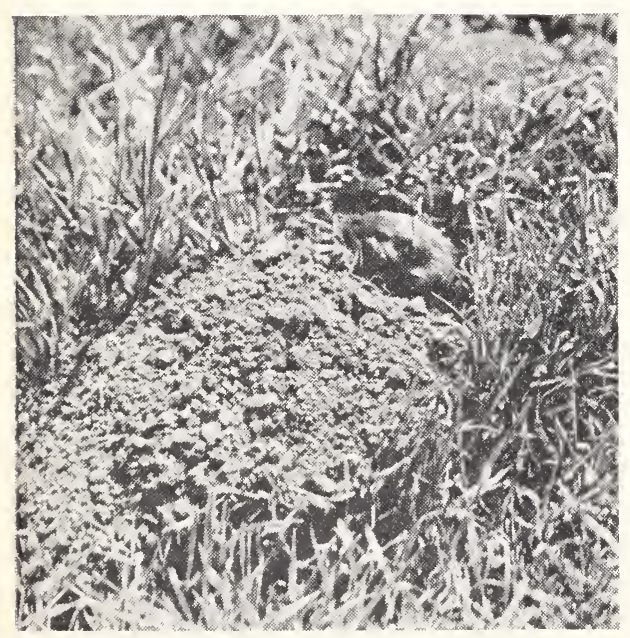

Fig. 3. Live pocket gopher at mouth of lateral tunnel. Loads of earth from below ground have been pushed out to the front and sides so the mound has a crescent-like form with the opening at the center. A feeding exit would have less earth around the entrance. abandoned tunnels). After the lateral has been closed a central depression in the mound usually indicates where the tunnel opened. The position of successive mounds often indicates location of the main tunnel. New mounds often are dark because of moisture in the freshly removed soil; plants covered by a mound become blanched (by loss of chlorophyll) after a few days. Trapping is most productive in or near fresh mounds.

Gophers also make short almost vertical laterals when coming up to feed on vegetation; these are later closed with soil level with adjacent ground surface. The nest is a hollow ball of finely shredded plant fibers (resembling excelsior) commonly filling a chamber about 8 inches in diameter, and somewhat deeper in the ground than most of the tunnels. Often there is a steep "sump" near the nest, possibly to drain adjacent tunnels; some sumps are 2 to 5 feet deep. Food is stored below ground, near the nest or in other enlarged chambers.

Ordinarily each burrow system is inhabited by one gopher, save when a female has young. Adjacent systems, if connected, are usually walled off by firmly plugged earth. After the occupant 


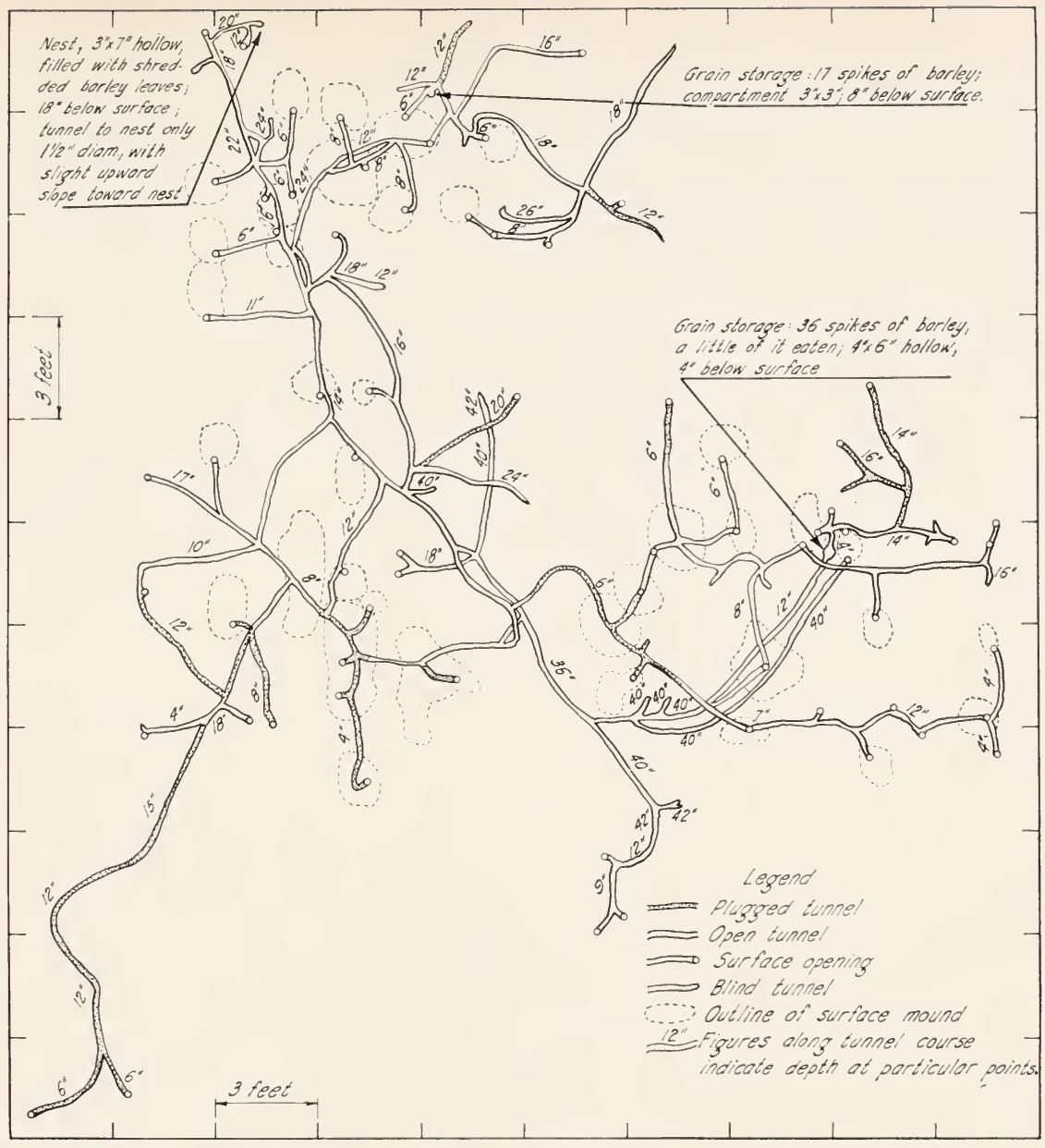

Fig. 4. Plan of the burrow system of a pocket gopher; excavated at Davis.

of a system is killed another may move in. Gophers are active throughout the year (even in mountain areas where they work in and under snow, putting excavated earth into snow tunnels). Fresh workings may be found at any time, but surface activity decreases on hot dry lowlands during the summer; on unirrigated areas of the interior valleys there may be no new mounds at that season. Activity also lessens during and after a heavy rain. Breeding. On uncultivated and unirrigated areas there is a limited breeding season some time after the rains begin, when green forage becomes plentiful. In such places there is usually only a single litter of young, but in irrigated lands having continuing green forage (such as alfalfa fields) gophers breed almost throughout the year and a female may bear three litters. At altitudes of 5,000 feet or higher, breeding is mainly in June and July. Litters average 5 to 6 , but vary from 1 to 13. The frequency of pregnancies increases with age and size of females (Miller, 1946).

Young remain in the nest for several weeks; upon leaving they often wander overland to start tunnels in new places. Adults sometimes go abroad on the surface, and may invade gardens and fields previously free of gophers. The following 
dates indicate approximately when most of the young disperse (although some appear both earlier and later) : southern California, March 20; San Joaquin and Sacramento valleys, April 1; Owens Valley, April 15; foothills of the Sierra Nevada, April 30; northwest coast region, May 15.

\section{Damage}

Production of alfalfa can he seriously reduced by destruction of root crowns. Cophers damage truck plants by eating the roots, and in flower gardens valuable plants - especially those with bulbous roots-are often destroyed. Gophers cut roots of trees and vines and gnaw the hark of trees, at times completely girdling the latter so that they die unless saved by bridge grafting. Gopher burrows in home gardens often divert water used for irrigation. Burrows in banks of ditches and canals may cause breaks in the earthwork through which water is lost and adjacent lands are flooded.

On wild lands, gophers may be beneficial in the long run. Pasture lands cleared of them often show an immediate increase in the amount of forage available for livestock, but how long this might continue is unknown. On unplowed land gophers "cultivate" by bringing much fine soil to the surface. New mounds usually support riclı growths of annual plants and grasses. Whether their burrowings contribute to or serve to check erosion on slopes probably depends upon local conditions. The rich sediments of valley bottom lands have resulted from erosion at higher altitudes in past geologic time; to this process pocket gophers have contributed.

\section{Control}

Persistent effort will reduce and even eliminate gophers over a considerable area. Prompt attention to the first evidence-new mounds-in a garden will often save valuable plants. Control may be practiced at any season but is most effective as green surface vegetation is starting, when the gophers are most active, and before their young are born.

Methods of control include: trapping; poisoning; gassing; flooding; exclusion; and encouragement of natural enemies. There is a common but mistaken belief that certain kinds of plants are "gopher repellent;" no sound evidence supports this idea.

\section{Trapping}

Because pocket gophers live in small underground burrows, special types of traps are required. The most successful and widely used is the Macabee trap, about $51 \frac{2}{2}$ inches long and made of wire except for the trigger (fig. 5). It springs
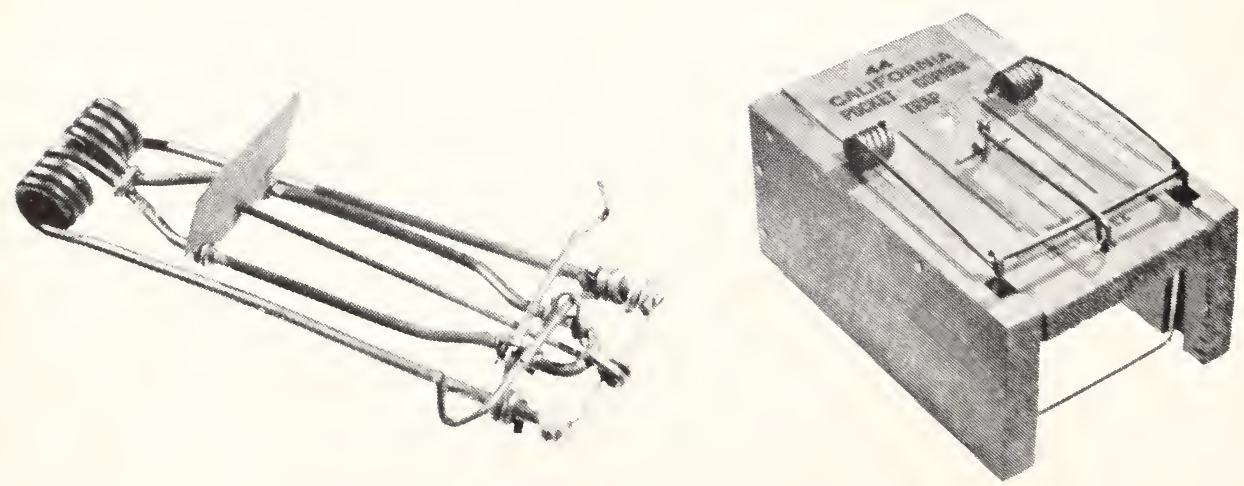

Fig. 5. Traps for pocket gophers, shown as set for use. Left, Macabee trap, right, California pocket gopher trap of wood. 
when a gopher pushes against the flat trigger pan. Next in popularity is a box type with choker loop which is released when the gopher seizes a baited trigger. Variants of these and other kinds have been designed and marketed, but none has had any lasting demand. Several types of "gopher guns" using shotgun or smaller cartridges also have been made; their efficiency is low and they can be hazardous for the user.

Trapping is especially useful in gardens, orchards, small fields, and the banks of irrigation canals. It is probably as effective as any other single method of control. Special traps are safe to handle and require only a limited amount of skill and a little digging to place them. On one ranch near Davis a workman handled about 75 traps, set usually in pairs. These required about 5 hours daily to examine and reset as needed, and on 3 successive days took 38,40 , and 37 gophers, respectively. A trap is the preferred means of capturing an individual gopher.

Gophers are often caught by setting one trap in a lateral tunnel, but there are failures when an animal merely buries the trap with soil. Best results are ob-

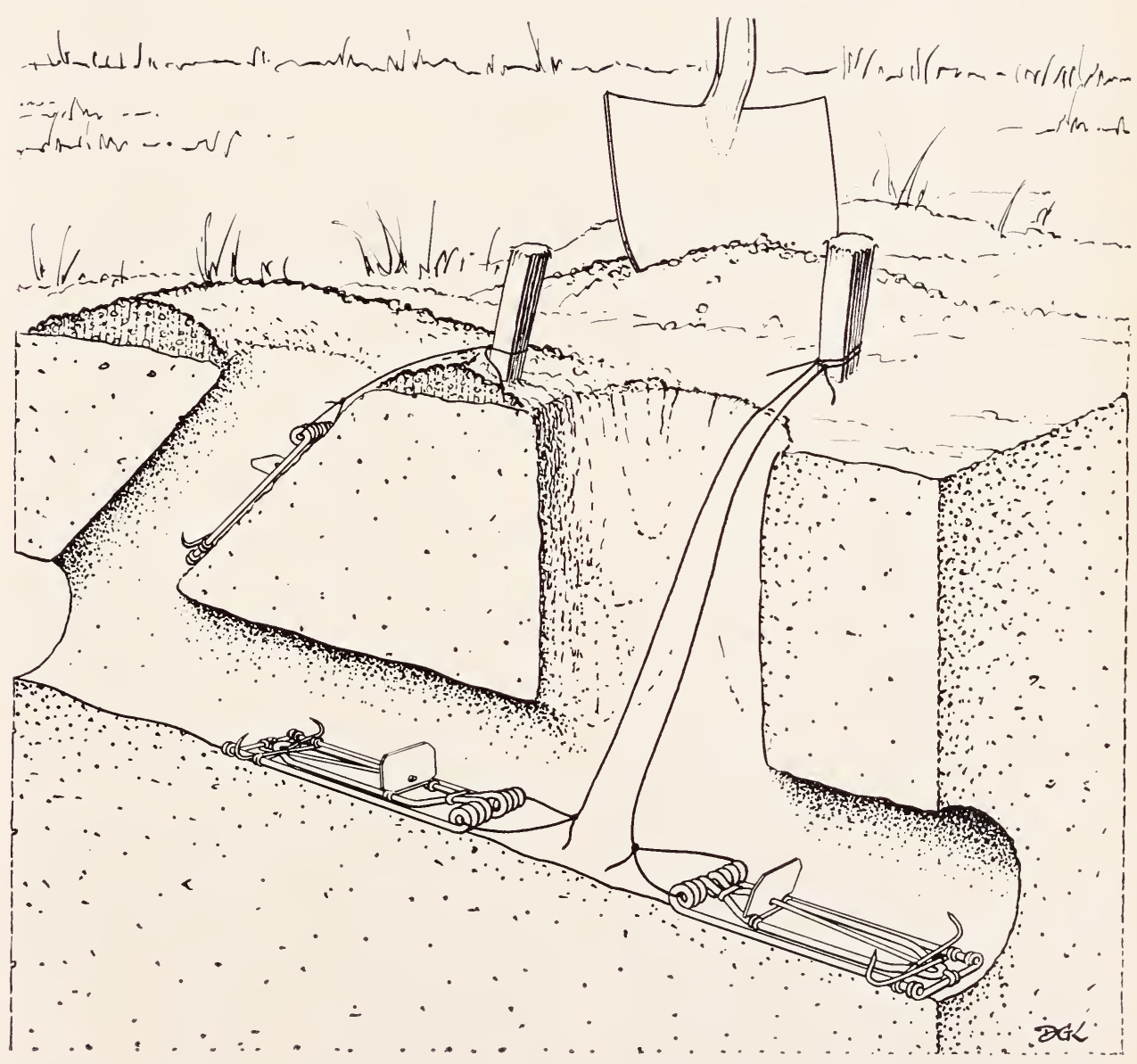

Fig. 6. Methods of placing traps for pocket gophers. Left, single trap in lateral tunnel; right, hole dug with shovel and two traps set in opposite directions in main tunnel. Each trap should be fastened by wire or cord to a stake tall enough to be seen easily in the field. 
tained by digging into the main tunnel and setting two traps, one in each direction (fig. 6). This requires more traps and work but the results are quicker and more certain, with greater catch per trap site per day. A lightweight shovel serves for digging down to the main run, and a 12-inch stout iron spoon is useful for finding the main run and placing the trap properly. The freshest mound should be selected and the probable location of the main run determined by noting the argle of the dirt-plugged hole. Mounds are usually 6 to 15 inches distant from the main run, and laterals nearly at right angles to it.

How to set traps. Push the handle of the spoon into the ground where the lateral is believed to be located; if the handle enters an open lateral it will drop through the opening. Should the lateral he filled loosely with dirt, the drop will be less noticeable but still plainly felt. If the lateral is plugged tightly, it is necessary to dig down a little distance with a shovel before probing again; if this fails, a new mound should be tried. When a lateral is located, follow it down to the main run, which is usually kept open by the gopher. With the shovel, clear a place so that a trap can be set in each direction. Clear out the main run with the spoon, to gain clearance for the jaws, hut disturbing it no more than necessary. Set the treadle, or pan, so that a light touch will spring the trap and p'ace the trap, jaws forward, well into the hole. A little loose dirt may be left in the bottom of the tunnel to cover the prongs and front end of the trap when the latter is pushed into place. Press the trap down firmly so that it will not slide backward if a gopher pushes against it. Many people cover the burrow with a clod or a handful of grass or alfalfa so that little or no light reaches the trap. A gopher instinctively closes all open burrows tightly, hence a trap placed in an uncovered hole may be sprung by the dirt which the gopher pushes ahead in plugging the hole.
Each trap should be fastened by a light wire or cord to a stake or some other above-ground object to mark its location. This also prevents the trap from being dragged far back into the tunnel by a wounded gopher, or from being removed by a predatory animal when it holds a gopher. If stakes 2 or 3 feet high are used, traps are less likely to be lost in cultivated fields while they are set. Stakes are essential in alfalfa fields or truck patches; without them, many traps will be lost. On a ranch where traps are used regularly it is well to have some distinctive kind of stake so that all the farm laborers will recognize gopher sets. For most efficient use of traps and best results, each setting should be inspected morning and evening, or oftener.

When the box type of trap is used, the tunnel must be enlarged to accommodate the trap and space left for the spring on the top to move upward when released; the bait can be a piece of carrot, sweet potato, a prune, or some raisins.

Occasional gophers prove difficult to trap. In sucl cases take a Macabee trap and move the treadle forward about an inch and a half, placing the wire which carries the treadle below instead of above the two longitudinal wires. Cut off the wire trigger to meet this change, then bend the treadle backward at right angles to its former position so that it will lie parallel with the trap and ground below. Set the trap so that it will spring easily. Put a bit of loose cotton under the treadle to keep out dirt, place the trap in the rum, and cover the whole trap lightly with a thin layer of loose earth.

After having put out traps, tramp down or kick the tops off all nearby mounds so that on the next visit any new mounds will show where gophers remain and where further effort is needed.

\section{Poison Baits}

The gopher's external cheek pouches are lined with fur and will not absorb poison; therefore it is necessary to use stomach 


\title{
FORMULA 1
}

\section{For Pocket Gopher}

\begin{abstract}
Cut baits of sweet potatoes, carrots, or parsnips . . . . . . 4 quarts
Strychnine alkaloid, powdered . . . . . . . . . 1/3 ounce

or strychnine sulfate, powdered . . . . . . . 1/2 ounce
\end{abstract}

Cut the vegetables into pieces about $1 / 2 \times 1 / 2 \times 1 \frac{1}{2}$ inches. With a pepperbox or other siffing device dust the strychnine on the baits, a little at a time, meanwhile turning them over and over, until all are evenly coated. Put the baits in a covered container and use as soon as possible. Unused poison baits may be kept in cold storage for at least 6 weeks without loss of potency (Miller, 1953). Label both the bucket and the sifter: POISON.

Dried fruits or grains are sometimes used for baits but are far less efficient than vegetables. It is unnecessary to use sweetening or scented materials on baits, as they do not improve efficiency (Miller, 1950, 1953).

Carrots and sweet potatoes are commonly infested with root nematodes. To avoid spreading these nematodes, discard about $1 / 2$ inch of the small end of the carrot and peel the remainder to a depth of about $1 / 8$ inch; peel sweet potatoes to a depth of $1 / 4$ or $3 / 8$ inch. Peelings and discards should be burned or disposed in garbage, not buried or put into a garden mulch pile.

Strychnine-coated grain baits are commonly available in garden-supply stores, but they kill far fewer gophers than poisoned root vegetables.

\section{(See Page 6-General Precautions with Poisons)}

poisons. Strychnine (alkaloid or sulfate) is effective for this purpose. The baits must be of some material relished by gophers, placed in the main runs with little disturbance; if put on the surface baits will not be found by gophers and may harm other animals, wild or domestic; and if put into laterals or open holes they may be buried or pushed out in the soil. Root vegetables dusted with strychnine are far the best baits (formula 1).

\section{Placing Baits with a Probe}

Baits of any kind are placed in main runways by use of a special probe (figs. $7,8)$, with which burrows can be easily located and baits inserted with a minimum of disturbance. The main shaft of the probe is of $1 / 2$-inch pipe about 40 inches long, divided by a screw coupling so that the probe can be taken apart for ease in carrying. A conical point of solid metal of the same diameter as the pipe is welded on one end. To the opposite end a 12-inch length of 7/16-inch steel rod is welded. The free end of the rod is enlarged by adding "hard-surface" steel and then ground to a carrot-shaped tip about $1 / 2$ inch in diameter at the base and tapering to a sharp tip. For work in loose sandy soil the base may be slightly larger, and for hard earth the enlargement may be omitted. One (or two) side arms are added; these may be welded in place or inserted by means of pipe T's. The side arms may also be designed with a collar and set screw which permits adjusting their position on the shaft of the probe to apply downward pressure with either the hand or the foot. (A short length of rubber hose may be slipped over each side arm as a convenience to the user.)

To use the probe, sink the slender end into the ground between the rows of gopher mounds. Repeat until the main tunnel is struck, when the tool will drop suddenly about 2 inches. Enlarge the 


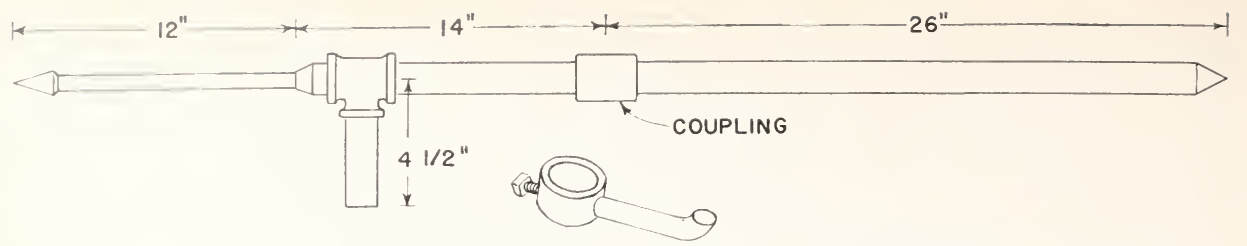

Fig. 7. Probe for locating pocket gopher tunnels to insert poisoned baits. The shaft may be in one piece or divided by a pipe coupling for convenience in carrying when not in use.

opening by rotating the probe, or by using its larger end, and then drop in a piece or two of poisoned bait. Put baits in each tunnel at two slightly separated places, then close the hole with your heel. As the work proceeds, tramp down or kick off the tops of all mounds so that new mounds made by surviving gophers ran be easily seen and additional baits can be put into the tunnels as needed.

About 40 per cent more baits are taken when inserted into an opening made by a probe than when tunnels are opened by a shovel or spoon. The probe method is also faster: a trained man using a probe can treat several hundred holes in a single day. Probing is easiest when the soil is damp and soft down to the level of the

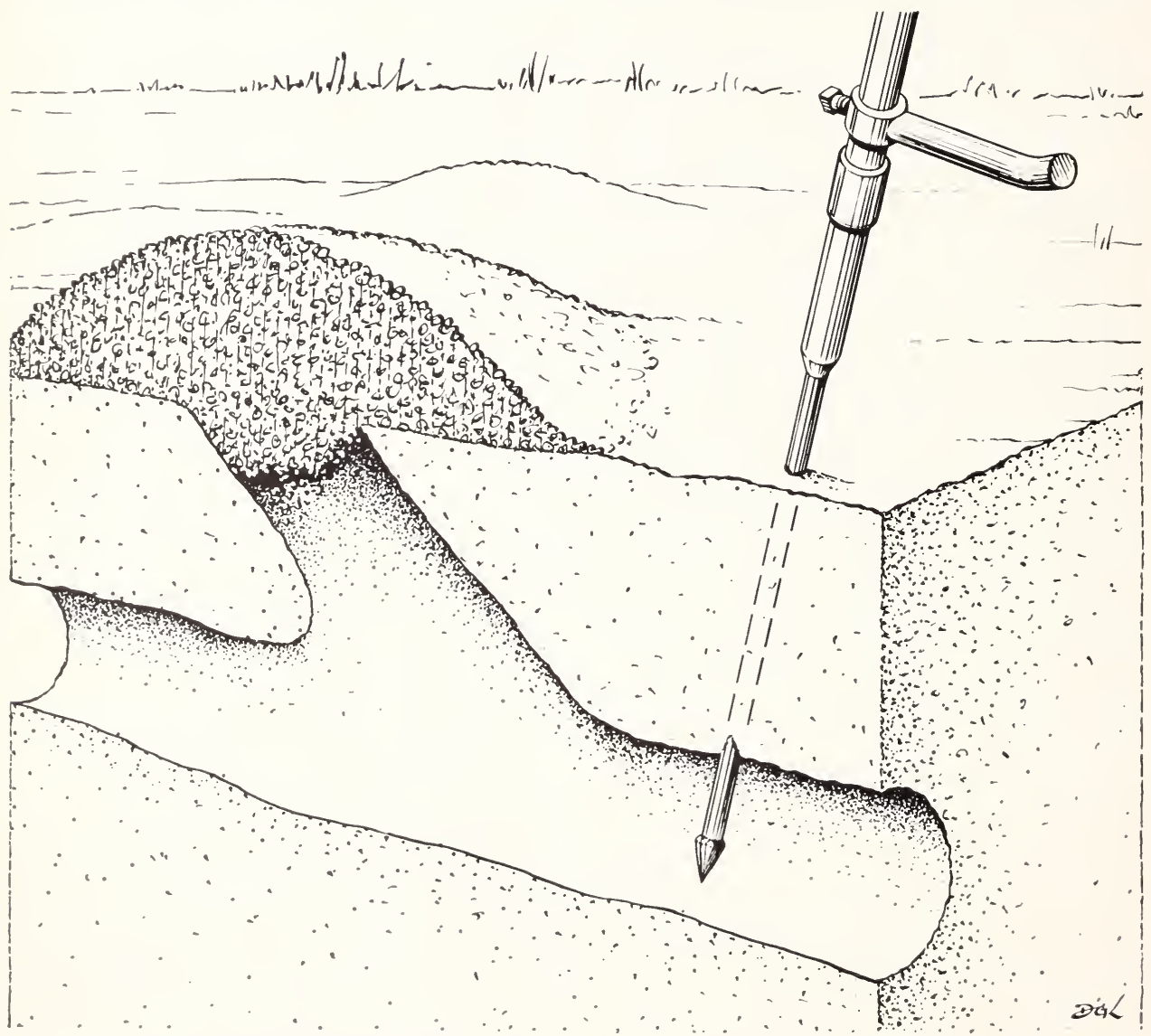

Fig. 8. Use of probe for placing pocket gopher baits; when pushed into the ground, if the probe suddenly drops about 2 inches, a main tunnel has been located; then the probe hole is made large enough to insert a poisoned bait. 
main tunnels; it is unsatisfactory in sand. In adobe soil that cracks when dry, the probe drops as easily into a crack as into a burrow; on finely cultivated land the dry surface soil should be scraped back before closing the hole with a clod of earth.

The best time to use the probe is during the first cool weather of autumn just before the first good rains, and in spring when the soil is moist and gophers are most active. Before the green vegetation is tall and abundant, mounds are conspicuous and burrows are easier to locate. Land should be gone over thoroughly before the major spring peak in breeding. Alfalfa fields, affording an abundant and continuous food supply, support large gopher populations and often are harder to treat effectively than orchards or open fields. Successive treatments may be necessary to eliminate survivors of the first application.

When use of a probe is impracticable, main runs can be opened as in setting a trap. Using a slender pointed stick, a poisoned bait is placed 12 inches back in each runway, which is then tightly closed. The hole should be opened 2 days later; if the bait is gone and the hole remains open, the gopher probably is dead.

Gophers are most apt to gnaw or girdle orchard trees during late summer when the ground is dry and green vegetation is scarce. Thus, when gophers are doing serious damage, and their speedy destruction is most desirable, probing is least easy, and it may be necessary to dig to the main runways to place poisoned baits. In a garden, nursery, or lawn where it seems desirable to use poisoned baits rather than traps, formula 1 should be employed.

When gophers are numerous in land to be planted in vegetable crops or orchard, they should first be far reduced. After a vigorous poisoning program, the land can be plowed with a subsoiler to 18 to 24 inches below the surface, thus destroying all but the deepest tunnels. Surviving or newly invading gophers can be recognized by their mounds, and should be destroyed promptly.

Approximate costs for controlling gophers in alfalfa by poison baits can be estimated. Assuming a 5-acre field averaging 20 gophers per acre, strychnine alkaloid at $\$ 2.00$ per ounce would cost 42 cents and the carrots (8 cents per pound, 25 per cent wastage) 40 cents. Labor to prepare and place the baits, including retreatment for gophers surviving the first application, would require about 4 hours; at $\$ 1.25$ per hour the cost would be $\$ 5.00$. The total per acre cost would be $\$ 1.10$ and for each gopher destroyed about $1 / 2$ cent for materials and 5 cents for labor (Miller, 1953). A field freed of gophers will yield appreciably more crop, and will thus more than offset the cost of control.

Fresh baits require both time and labor to prepare and they tend to mold within a few days after being placed in the burrows. In an attempt to offset these features a gopher pellet. containing bait, strychnine, and a mold inhibitor, has been manufactured. Up to five pellets are to be placed with a probe in each burrow system. Tests by the Department of Zoology of the University of California at Davis showed the pellets were less efficient than fresh baits; percentage kills were: pellets, 44 per cent; strychnineprune, 57 to 73 per cent; strychninecarrot, 77 to 80 per cent.

\section{Machine Poisoning}

"Burrow-building" machines are now in use for gopher control on large acreages. Using tractor power, the machine drags the tip of a slender hardened tubular tool about 8 to 10 inches below the surface (shallower in orchards) to form an artificial burrow into which poisoned grain is feed through the tool. Baits consist of lightly rolled oat groats, whole oats, or rolled barley, carrying 3 pounds of strychnine alkaloid per 100 pounds 
of grain. Parallel burrows are made at 20- to 25-foot intervals, and along either side of each levee in fields of flood irrigated alfalfa. One to three pounds of bait is used per acre. In Colorado during 1959 labor, materials, and tractor rental were estimated at $\$ 1.50$ per hour when treating 50 acres per day at a rate of 10 minutes per acre. It is said that efficiency of control is 90 to 95 per cent, but no detailed reports have been published to date. Machines differing in some structural details have been built and used in California and Colorado. Detailed drawings for building machines are available from the agricultural experiment stations in those states. (Kepner and others, 1962; Ward and Hansen, 1960.)

\section{Poisonous Gases}

These are not often effective against pocket gophers. The extent of the burrow system, the chance for leakage of gas through the softer earth of laterals, the closeness of the main runs to the surface of the ground, and the fact that gophers may quickly plug off their burrows when a poisonous gas is detected and so escape destruction all make use of gas unsatisfactory. Tests at Davis gave percentage kills as follows: methyl bromide $(58 \%$ or less) ; carbon bisulfide (18 to $26 \%$ ) ; chloropicrin $(48 \%)$; calcium cyanide to produce HCN gas (14 to $30 \%$ ); burning nitrocellulose film (44 to $54 \%$ ). (Miller, 1954).

Trials at the same time of strychninecarrot baits yielded 80 per cent kills. For small areas, where cost is not important, gas may be tried but with less expectation of success. The exhaust gas from an automobile, containing carbon monoxide, may be piped into gopher runs hy use of a rubber lose. Various commercial gopher "bombs" have been offered for sale; these are lighted and placed in the burrows to generate a gas fatal to gophers, but they have not been satisfactory.

\section{Flooding}

When irrigated croplands and orchards are periodically flooded, gophers are either drowned or forced out of their burrows. Some survive in the levees, but others, driven into the open, seek the higher borders of the field and can be easily killed by a good dog or a stroke of the irrigator's shovel.

\section{Exclusion}

Small flower or vegetable gardens or home orchards that border on wild lands sometimes need special protection against gophers entering by burrows or overland. A fence of small-mesh wire, sheet metal, or concrete extending about 24 inches below ground and about 10 to 12 inches above will usually give protection. In lighter soils, greater depth may be desirable. If the fence is extended to 36 inches above ground, it will also exclude rabbits.

Young trees can be protected against gophers by a cylinder of wire netting (1inch mesh or smaller) 12 inches in diameter and 18 inches tall that is sunk in the hole around the tree when planted; the top of the wire should be a little under the surface of the ground to avoid difficulty later in cultivating around the tree.

Trenching is successful for small-scale operations. A steep- or vertical-walled ditch 18 inches wide by 24 inches deep is dug around the plot to be protected. Open-topped 5-gallon cans are sunk at intervals of 25 feet so that their tops are level with the bottom of the ditch. Gophers getting into the ditch will fall into the cans and be unable to escape. If gophers are damaging the banks of irrigating ditches, lining the interior surface with concrete will help to reduce the damage. A well laid 1-inch coating, troweled smooth on the exposed surface, is adequate.

\section{Encouraging Natural Enemies}

Both barn owls and gopher snakes eat 
gophers. The barn owl, which nests in barns, steeples, palm trees, and holes in cliffs or earth banks, subsists almost entirely on rodents. After digesting a meal, an owl regurgitates the fur and bones as a "pellet" dropped below its roost, and analyses of pellets from many roosts show that pocket gophers are often the chief item of diet. It is known that one pair of owls may take three to six gophers daily when feeding their young. This owl rarely eats birds and never kills poultry. The gopher snake eats gophers also, but it is also true that these snakes sometimes take eggs from wild birds or from henhouses.

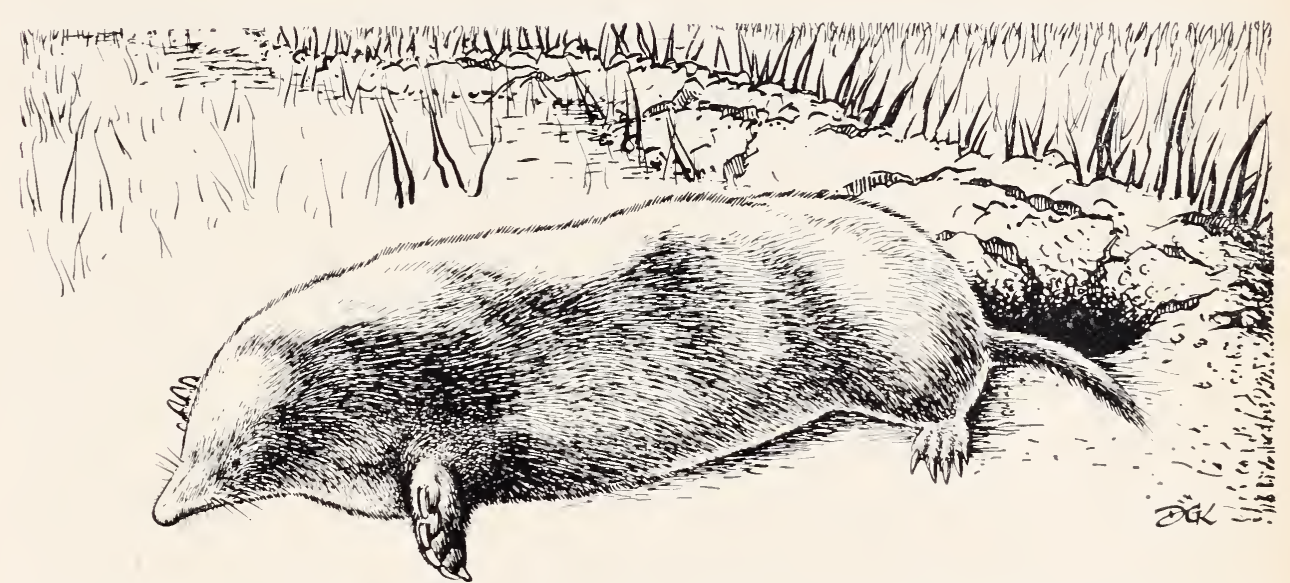

Fig. 9. The mole. Distinctive features are the slender snout, short needlelike teeth, large fore feet and claws, velvety fur, and short tail. Head and body about 5 inches, tail $1 \frac{1}{2}$ inches. Compare with fig. 1. Beyond the mole is a surface tunnel or run.

\section{MOLES ARE NOT RODENTS; their work is often confused with that of pocket gophers, but different control measures are needed.}

Moles (genus Scapanus; fig. 9) are not rodents; they belong to a different group of mammals (Insectivora). Their habits, food, and methods for control are unlike those of gophers. Both animals live in the soil, make underground tunnels, and put up earth mounds on the surface.

The mole has a slender, conical snout, no external eyes or ears and no cheek pouches. It has small, needlelike teeth, and forefeet with large palms and heavy claws. The short silvery black fur is of velvety texture.

Moles are common in the northwestern humid coast belt of California south to Monterey Bay; some live in the river bottoms of the lowlands and in other places with damp soils, as in the foothills and mountain meadows, and locally in gardens and citrus groves of southern Cali- fornia. Irrigated pastures are providing places for moles where they could not previously survive.

\section{Habits}

Two different kinds of workings are made by moles: tunnels or runs just below the ground surface, and deep burrows; the first type is commoner and more extensive. In searching for food a mole moves just under the ground surface and pushes up a low rounded ridge (fig. 9), within which is a tunnel or run where the animal may travel again. The deep burrows of the mole, like the main tunnels of gophers, are farther below the ground surface; the earth from such excavations, instead of being pushed out of an open tunnel, is forced up from below, and there is always a central core of loose 


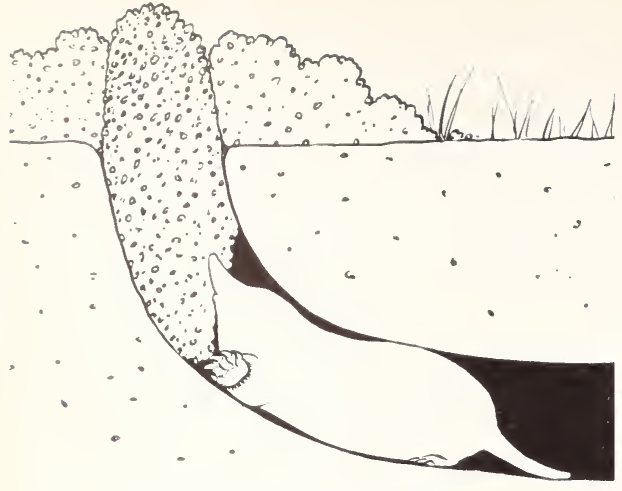

Fig. 10. Mole hill and deep burrow of a mole. Successive loads of earth are forced up as a plug through the lateral tunnel to form an irregular surface mound; the tunnel is never open. Compare with fig. 2. earth, so that the surface of the mound resembles a miniature volcano (fig. 10). The runs and surface mounds disfigure lawns, golf greens, and flower beds. In making them the mole may loosen or uproot small plants or cut the roots of larger ones.

Moles partly compensate for the damage they do by eating soil insects and their larvae; these, together with earthworms, are their principal food. But moles also eat sprouting seeds and bulbs to a limited extent and they cut roots of some plants when making their runs or tunnels.

\section{Control Methods}

Trapping. For one or a few moles,

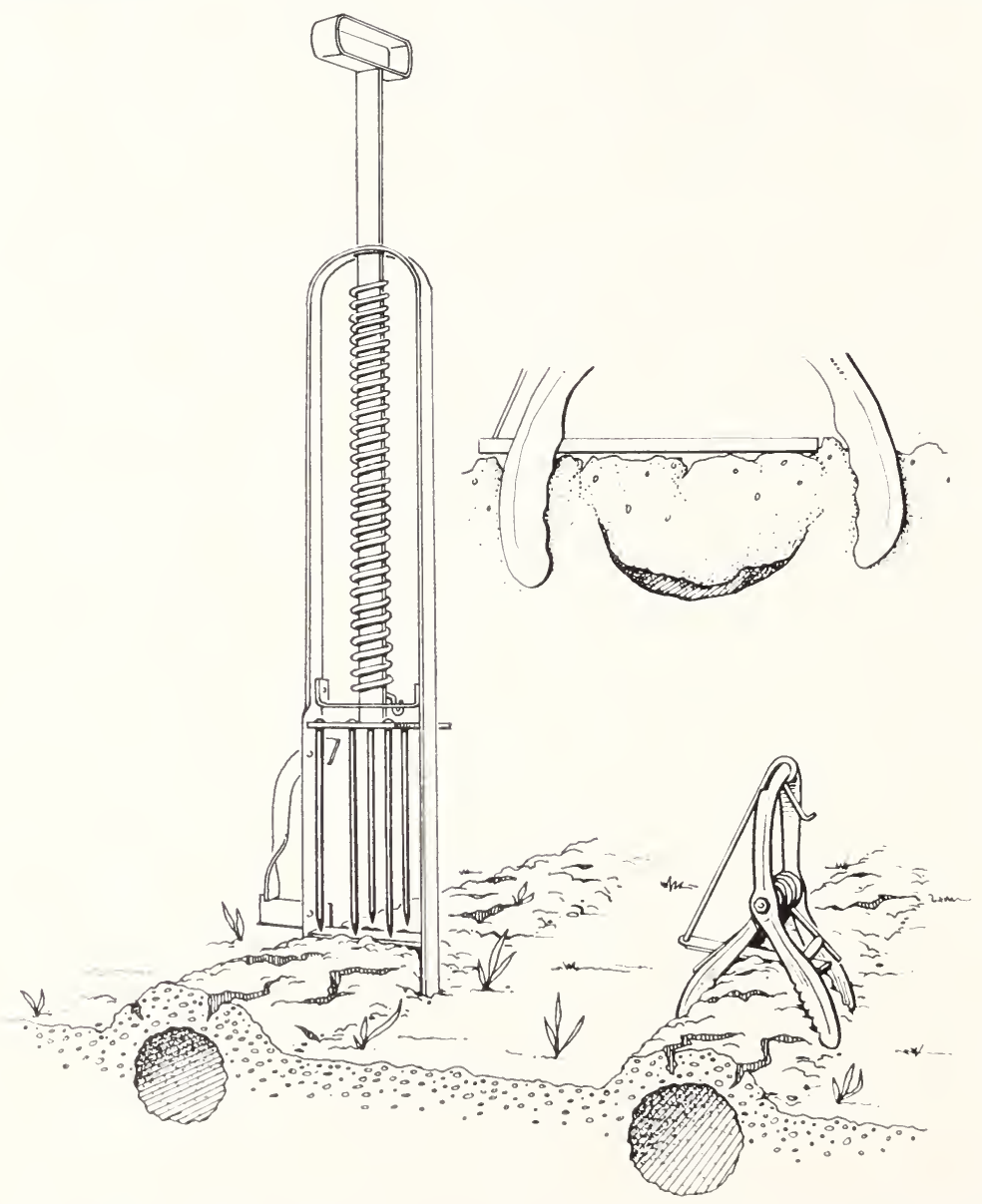

Fig. 11. Mole traps as set, Reddick at left, Out-o'-sight at right. Inset at upper right shows how trigger pan should press on soil above run. 
the persistent use of traps is recom. mended. "Choker loop" traps are used in the Pacific Northwest, the Middle West, and Europe but are seldom available in California stores. Two loops (or diamonds) of wire or metal are forced into the earth to encircle a run, and the trap is sprung by a trigger pan touching the top of the ridge. Two traps commonly sold in California are the Out-o'Sight and the Reddick (fig. 11). Both traps are pushed down, crushing the top of the run (fig. 11, upper right); the treadle is raised as the mole enlarges the run to its former size. These traps are released by the upward pressure of the mole's body against the earth over the run. The Out-o'-Sight is a "scissor-jaw" type, and the Reddick has several downward-directed spears. The spring of the first causes the two pairs of jaws to clamp the animal firmly and fatally; the spears of the second are driven downward through the earth and into the mole's hody. The choker loop is generally reported to be more effective than the spear type.

To determine which runs are in use, press down the soil at various places on several surface runs; if in use, the mole, in passing, will raise the ridge again. Then press the soil down lightly once more and set a trap, pushing it down enough so that the trigger pan rests firmly against the earth over the run. On its next round, the mole will force the trigger upward and release the trap. In dry weather, wetting the ground over a run is reported to encourage a mole to return through the run; then a trap may be set.

Repellents and gases. Lye, paradichlorobenzene ("PDB"), or naphthalene, introduced into mole runways, a teaspoon every 10 or 15 feet, is sometimes helpful in repelling moles. Calcium carbide (used for generating acetylene) has been tried for the same purpose in damp soil, with limited succes. Calcium cyanide dust blown into mole tunels is thought to be of some value in control. Carbon disulfide poured or pumped into a deep runway will sometimes kill the mole tenant, but may injure or kill nearby plants. Exhaust gas from an automobile may be forced through a hose into a mole tumnel.

Poison baits. In Denmark, earthworms soaked in strychnine nitrate (about 2\% solution) have served to reduce mole populations when they are inserted in surface mole runs.

\section{For more information ...}

Further discussion of pocket gophers and moles can be found in the following publications:

Evans, F. C., and J. T. Emlen, Jr.

1947. Ecological notes on the prey selected by a barn owl. Condor 49: 3-9.

Howard, W. E., and H. E. Childs, Jr.

1959. Ecology of pocket gophers with emphasis on Thomomys bottae mewa. Hilgardia 29(7) : 277-358, 40 figs.

Kepner, R. A., and W. E. Howard

1960. Mechanical gopher-bait applicator. California Agriculture 14 (Mar.) : 7, 14.

Kepner, R. A., W. E. Howard, M. W. Cummings, and E. M. Brock.

1962. U. C. Mechanical gopher-bait applicator, construction and use. Univ. Calif. Agric. Extension Service, Publ. AXT-32:9 pp. Illus. (Out of print.)

Miller, M. A.

1946. Reproductive rates and cycles in the pocket gopher. Jour. Mammalogy 27: 335-58.

1948. Seasonal trends in burrowing of pocket gophers. Jour. Mammalogy 29: $38-44$. 
Miller, M. A.-Continued

1950. Eradication of pocket gophers. California Agriculture 4(Dec.) : 8-10.

1953. Experimental studies on poisoning pocket gophers. Hilgardia 22 (4) : 131-66.

1954. Poison gas tests on gophers ... less effective and more costly than poison bait. California Agriculture 8 (Oct.) : 7, 14.

1957. Burrows of the Sacramento Valley pocket gopher in flood-irrigated lands. Hilgardia 26 (8) : 431-52.

Ward, A. L., and R. M. Hansen

1960. The burrow builder and its use for control of pocket gophers. U. S. Fish and Wildlife Service, Special Scientific Report-Wildlife, no. 47: iii +7 p. Illus. (Processed) 


\section{GROUND AND TREE SQUIRRELS}

\section{Ground Squirrels have long been harmful rodents in California: They destroy crops, damage irrigation structures, and carry diseases}

The commonest ground squirrels in this (Citellus beecheyi and its subspecies, state are the large, long-tailed "dig- fig. 12) that inhabit most of the state ger," or California ground squirrels except the desert portions; the smaller,

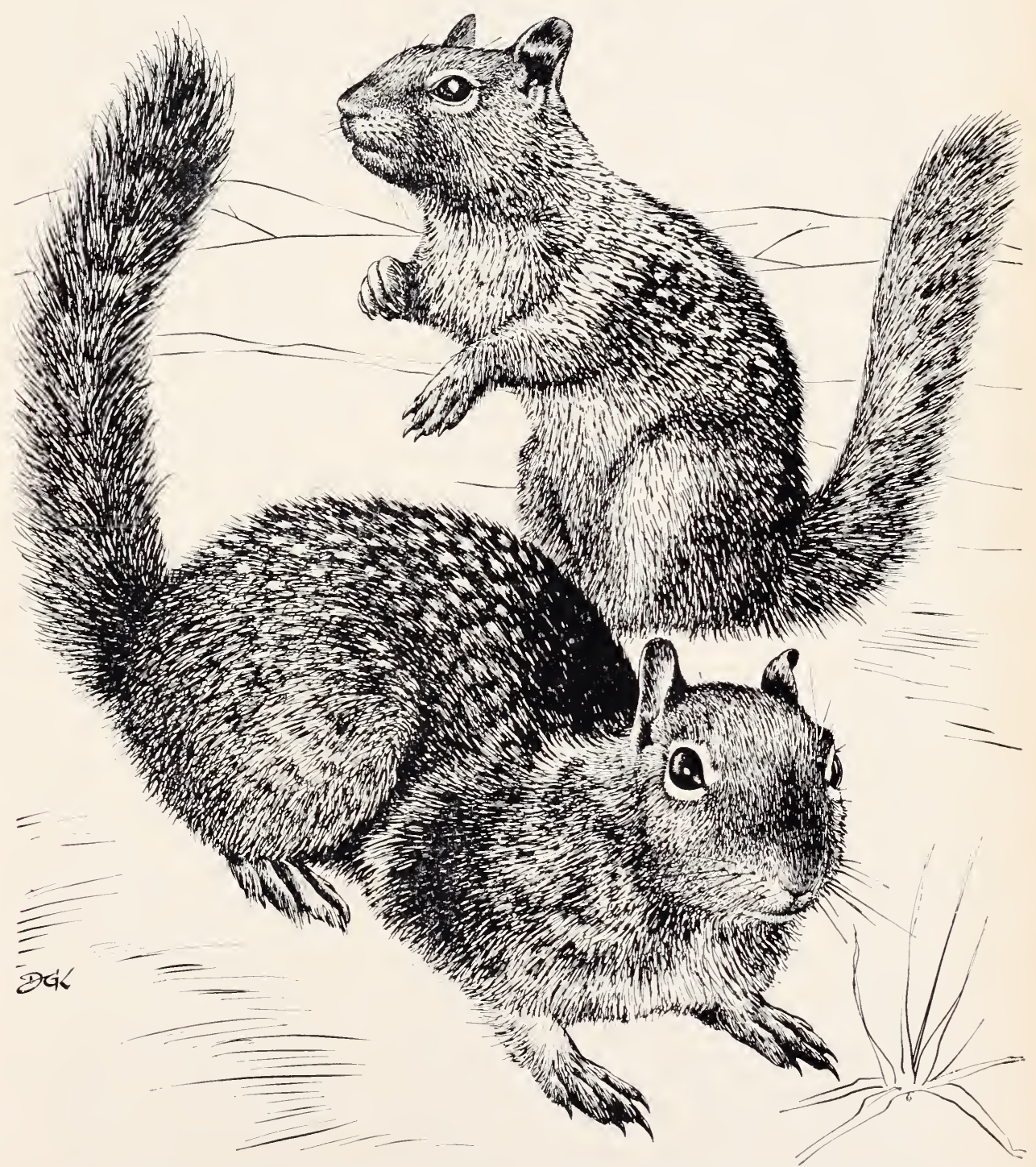

Fia. 12. California ground squirrels; head-and-body length $91 / 2$ to 11 inches, tail 6 to 8 inches. Above, Beechey ground squirrel; below, Douglas ground squirrel. 
short-tailed Oregon ground squirrel (Citellus beldingi, fig. 18) that lives in the northeastern plateau counties; and the golden-mantled ground squirrel (Citellus lateralis) of the higher mountains. The latter two species are discussed in this section, pages 34-35. Several smaller species live in arid regions, both west and east of the Sierra Nevada, but usually are of minor economic importance. For detailed accounts of species see Fitch (1948), Grinnell and Dixon (1918), Howell (1938). Storer and Usinger (1963), and Tomich (1962).

The "digger" ground squirrel is the largest in California; the head and body are about $91 / 2$ to 11 inches long and the tail from 6 to 8 inches long. The differences between the varieties are not important in economic relations, except that the Douglas ground squirrel, found north of San Francisco Bay and west of the Sacramento and Feather rivers, seems to be somewhat easier to control.

Every ground squirrel has two thin, moist, internal cheek pouches, opening just inside the lips, one on either side of the mouth, which are used to carry food. This characteristic is important in control because ground squirrels may be killed by absorbing poison baits through the lining of the pouches, as discussed on page 27 .

Ground squirrels were the most important rodent pests of agriculture in California for nearly 150 years, but they have been reduced by use of 1080 poison by the county agricultural commissioners.

\section{Habits}

Ground squirrels are ground-living; they find most of their food on the surface of flat country, hillsides, or embankments. Some climb trees, however, and may reduce yields from fruit or nut trees. Some live in open forest, scattered chaparral, or rock piles, but seldom in heavy growths of forest or brush. They are fairweather animals, active by day through. out the warmer season of the year and some species emerge on warm days in the winter months.

Burrows. All species of ground squirrels dig burrows, which they use for safety retreats, for shelter during very hot or rainy weather and during hibernation, for occasional storage of food, and for rearing their young. Burrows are made in flat lands, in hillsides or among rocks, and also in ditch, road, and railroad embankments. The entrances to squirrel burrows are always open.

The burrows (figs. 13, 14) of California ground squirrels average about 4 inches in diameter, and individual burrows are 5 to 30 feet or more in length. Most tunnels are within $2 \frac{1}{2}$ to 4 feet of the ground surface, but at Davis one was found $6 \frac{1}{2}$ feet deep and in Fresno County one was dug into 28 feet below ground level in a chalk pit. It is important to know the approximate volume of burrows when gas is used for control. The estimated volume of certain representative burrows ranged from 1 to 18 cubic feet. Some are simple short tunnels, but others have many branches. Often there are two or more openings. Some are colonial burrows occupied by several squirrels. The most complicated system yet found had 33 openings, a total of 741 feet of tunnels, and a volume of about 100 cubic feet. It contained six females and five males.

Feeding habits. During the rainy months, November to March or April, ground squirrels feed chiefly on green herbage. Seeds lying on the ground surface are hulled and eaten as found. Later, when the new seed crops begin to ripen, the squirrels gather seeds without hulling and put them in their cheek pouches, to carry off and hide in shallow caches excavated in the ground surface, or in crevices between rocks. Some are carried into the burrows for later use. Seeds of both wild and cultivated plants, particularly grains, are taken in quantity. In orchard districts these squirrels climb trees for almonds, walnuts, and the soft 

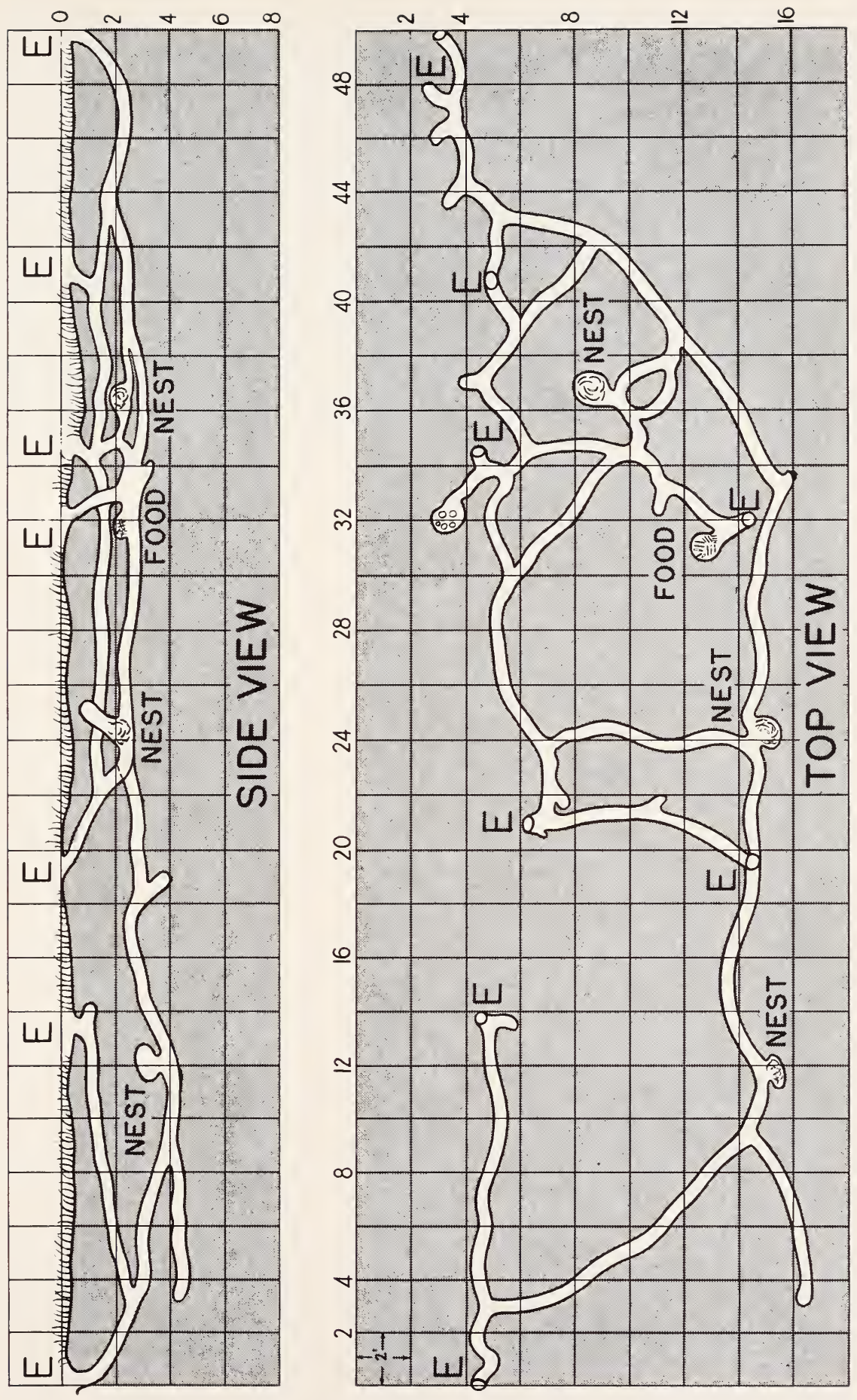

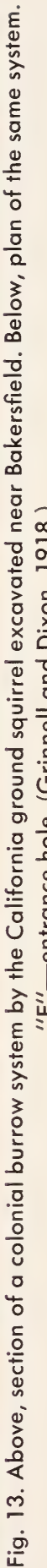




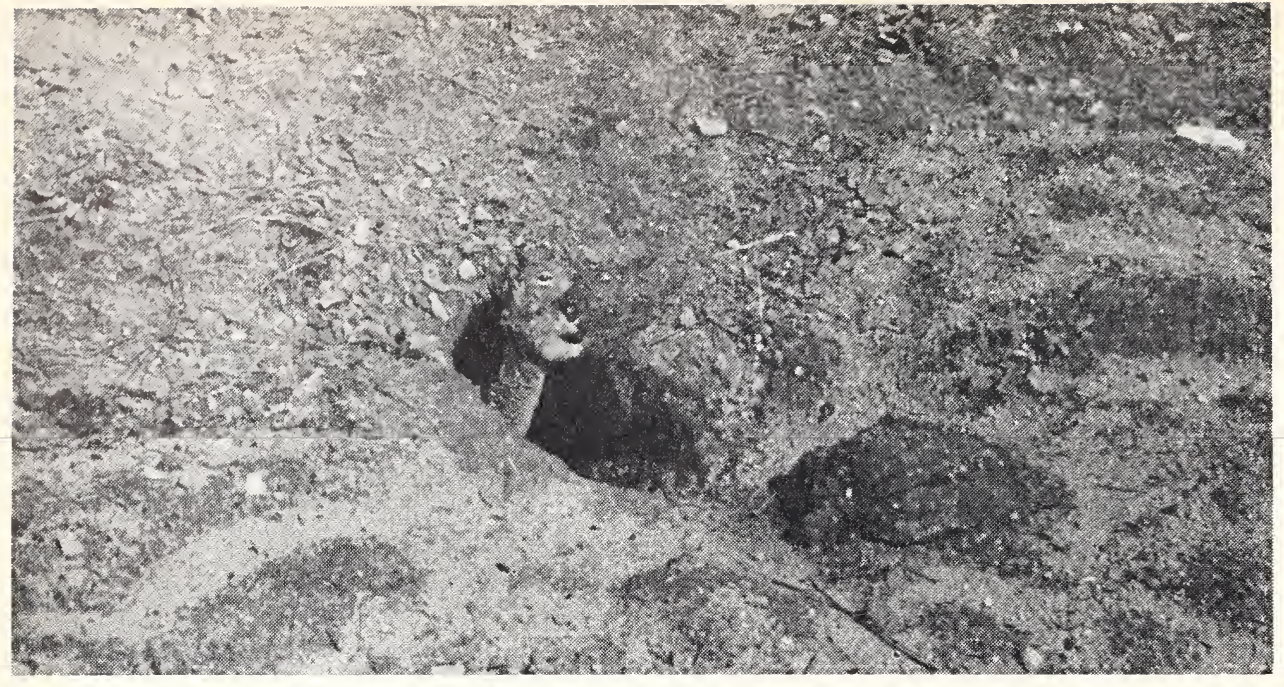

Fig. 14. Beechey ground squirrel at entrance to a well-used burrow from which trails lead out. (Photo by California Forest and Range Experiment Station.)

pits of growing peaches and apricots. Sometimes they may also forage in truck patches.

The feeding habits of ground squirrels cause greatest damage to grain and pasturage. In fields they dig up sprouting grain, and later pull down the ripening heads. After harvest they may eat and carry off quantities of grain from shocks and stacks. On pasture lands they may take a good deal of grass and herbage that could otherwise be used by domestic stock. Green forage eaten daily by the average squirrel has been estimated at $21 / 2$ ounces ( 70 grams) ; thus, 450 squirrels would eat as much as one steer. Both on isolated ranches and in welldeveloped areas, they often seriously deplete grain, nut, and fruit crops.

Hibernation and estivation. All California ground squirrels living at high altitudes and some of the population, mostly adults, at lower elevations hole up for a part of each year. Before this period of inactivity, each animal acquires much fat. After going below ground the squirrel plugs part of the tunnel just above the nest with earth to as much as 3 feet in length, and curls up in its nest below the tunnel plug. The burrow entrance remains open. While the squirrel is holed up, the rates of heartbeat and respiration are greatly reduced, and body temperature drops nearly to that of the burrow.

Emergence occurs in winter or early spring. Estivation ("summer sleep") begins as early as mid-May in the hills east of Livermore, and by late June in the hills of eastern Kern County, whereas it does not commence until early August in Siskiyou County. In mountain areas some do not enter hibernation until late in autumn.

This habit of a prolonged sleep below ground explains why old breeding adults suddenly appear in spring, after all squirrels active in a field during autumn had been killed and there seemed no chance for migration from the surrounding fields. During hot summer weather and in the fall and early winter, some of the squirrels may be underground and out of reach.

The exact extent of estivation among our ground squirrels is unknown because it is very difficult to follow an individual squirrel through its activities for any length of time. Therefore, it is extremely important to carry on intensive control in the late winter, spring, and early sum- 
mer, when all squirrels are active. There is also some doubt whether dormant animals are fatally injured by fumigating their burrows with carbon disulfide.

Breeding. The California ground squirrel in central California breeds mainly during the first half of the year, but some young are produced later in the season. In the interior valleys, females carrying young are most numerous in February and March. In Los Angeles County regular breeding activity was found to have begun by December, and in March 70 per cent of some 2,000 females examined there in 1925 were pregnant (Storer, 1930). The breeding season is somewhat later along the coast and in the mountains.

Ground squirrels probably produce only one litter a year. Of the average litter, possibly about five or six squirrels survive long enough to appear above ground. Where squirrels had been far reduced by control for two or more years and food for those remaining was greater, an average litter of nearly ten has been noted (Jacobsen, 1923).

The young grow rapidly and are seen in greatest numbers from late April until June, when they may scatter out to new territory or move to unoccupied old burrows. Control operations, therefore, should be especially intensive in late winter and early spring.

The rate of reproduction in ground squirrels is such that unless 90 per cent are eliminated in a given year there will be no general reduction in numbers. Theoretically, it would require 8 to 9 years of control at this rate to rid a given piece of land of squirrels entirely. And this would occur only if there were no reinvasion by migration from adjacent areas. While most squirrels move about but little, some have been known to migrate from 1 to 5 miles into new areas. These facts show that persistent and intensive work is needed to keep down the squirrel population. Furthermore, cooperative efforts by all farmers in a region are essential; otherwise cleared areas will be invaded by squirrels from lands where control is not practiced or is ineffective.

\section{Control Methods}

Various baits and several kinds of poison have been used for squirrel control. Whole barley and strychnine alkaloid (formula 2) have been most widely used by private landowners. In recent years, zinc phosphide (formulas 3 and 4) on oats or barley has found favor.

Strychnine-coated barley. This poisoned grain is used best in that part of the season when squirrels are "pouching" - that is, gathering seeds and grain in their cheek pouches to store or to carry to some favorite eating place. The barley is coated with the less soluble strychnine alkaloid, together with substances thought to disguise the taste. Kernels are picked up by the squirrels and placed in their pouches. There the strychnine coating is absorbed through the delicate lining of the pouches, killing the animals. At other times of year, the squirrels take scattered seeds as found, eating each kernel after quickly removing the hull, and the strychnine coating usually does not have a chance to affect them. Sometimes squirrels will refuse to take strychninecoated grain. Where grain or other crops are maturing, the animals may turn to these and avoid poisoned bait.

The exact time to use strychnine grain for best results must be determined by the person doing control work. It will vary according to locality and year. The activities of the squirrels should be observed. Prebaiting part of an area with unpoisoned grain is a simple test which should first be made to determine whether the squirrels will take and "pouch" the bait used.

The poisoned grain should be scattered by hand or with a spoon on hard bare ground on or near the cleared surface of squirrel runways. It is less likely to be found and eaten if dropped in tall grass or on the soft earth around bur- 


\section{FORMULA 2 \\ For California Ground Squirrel}

Barley (clean whole grain)
Strychnine
Bicarbonate of soda (baking soda)

Mix the strychnine, baking soda, and saccharin together dry. Prepare the starch paste by sitiring 1 heaping tablespoon of dry gloss starch in a little cold water until smooth, pour into $3 / 4$ pint of hot water, boil and stir until clear. Add the dry strychnine, soda, and saccharin, then the corn syrup and glycerine; stir thoroughly. Pour the hot mixture over the grain, turning and stirring until each kernel is coated. Spread the coated grain out in a thin layer until the coating is thoroughly dried. Then store in a can or sack, properly labeled as POISON, until used.

\section{FORMULA 3}

\section{For California Ground Squirrel}

Oat groats (hull removed), lightly rolled

100 pounds

Zinc phosphide, powdered.

16 ounces

Lecithin-mineral oil

22 ounces

Warm the lecithin-mineral oil and stir in the zinc phosphide until evenly mixed. Pour this mixture, a little at a time, over the grain, stirring continuously and vigorously until all kernels are evenly coated with the blackish zinc phosphide. If rolled oats or rolled barley are used, about 32 ounces of oil is needed.

A small batch ( 10 to 20 pounds) may be made in a large bucket or pan with a wooden paddle or large spoon. Large quantities are best prepared in a steel or wooden drum (or clean cement mixer) with inside baffle plates and mounted at an angle on a shaft so that it can be turned easily. The drum should be revolved long enough to ensure even coating of all grain.

Workers should wear gloves and should avoid breathing fumes from the poison mixture.

\section{FORMULA 4}

\section{For California Ground Squirrel}

Oats, lightly rolled or whole, or whole barley

100 pounds

Zinc phosphide, powdered..

14-16 ounces

Petrolatum, or petroleum jelly.

32-40 ounces

Mix as for formula 3. More poison and petrolatum are needed to coat whole grains. Under wet conditions use the larger amounts of zinc phosphide and petrolatum.

\section{See page 6-General Precautions with Poisons}

rows. About 1 tablespoon should be scattered at each spot to cover 1 to 2 square feet; one quart provides 30 to 35 baits.

In farmyards or pastures where livestock are concentrated, the poisoned grain should be placed inside the squirrel burrows.
Failures in squirrel control will follow the use of strychnine barley when rain washes off the poison coating or when squirrels refuse such bait. Failure may also result when squirrels are feeding heavily on filaree. It is believed that the high tannin content of filaree will coun- 
teract the effect of strychnine. This viewpoint has been questioned by experiments with Wyoming ground squirrels which suggested that some individual animals could build up a tolerance to strychnine by repeated doses in amounts that were not enough to kill (Burnett, 1932). There are no similar data for the California ground squirrel, but ordinarily about 20 kernels are considered enough to kill the average of this species.

Quail, pheasants, and domestic poultry can withstand relatively large doses of strychnine. They often refuse strychninepoisoned baits-but this is no excuse for carelessness in placing poisoned grain.

Strychnine readily kills various wild rodents and birds, and, if taken in sufficient amount, can kill livestock. It is poisonous to man, even in small amounts, and therefore supplies of it should be locked up out of reach of children or ir. responsible adults.

Zine phosphide bait. Zinc phosphide is a dark gray powder with a slight smell of phosphorus. It is used on cereal baits with a "spreader" of mineral oil or petroleum jelly (formulas 3 and 4), which holds the poison to the bait and helps to protect against rapid deterioration in the presence of moisture. In damp places the zinc phosphide slowly produces phosphine $\left(\mathrm{PH}_{3}\right)$, a poisonous gas. Zinc phosphide baits should be prepared and handled out of doors or in a wellventilated building. Operators should wear gloves when mixing or distributing baits.

The principal baits used with this poison are whole barley, hulled barley, whole oats (lightly rolled), and oat groats (oats without hulls and the kernels flattened). Whenever possible, it is best to buy the prepared zinc phosphide baits from a county agricultural commissioner, who also sometimes has clean oat groats for use in preparing baits.

Zinc phosphide baits act directly when the squirrels eat or hull the poisoned grain. Such baits need not be stored in the cheek pouches to poison the animals. They may be used in spring and even in winter-over a longer season than strychnine baits. Zinc phosphide is most effective when seeds of grain and of range grasses are scarce. When such seed supplies are easily available, the results of poison distribution may be irregular or poor. One pound of prepared grain provides about 50 baits, which are placed in the same manner as strychnine-coated grain. Zinc phosphide baits may sometimes endanger livestock and game. Dogs have been killed by eating squirrels poisoned by zinc phosphide.

Anticoagulants. Warfarin, Pival $®$, etc., are anticoagulants; when eaten in sufficient amounts for several days they produce fatal internal bleeding (hemorrhage). Anticoagulants are sold under various trade names, but all packages are labelled with the name and percentage of the active ingredient (usually warfarin). Although used most commonly for control of house rats and mice, they can be em. ployed against ground squirrels for local concentrations or around farm headquarters where other poisons are too hazardous. For ground squirrels the anticoagulant concentrate $(1: 200$, or 5 per cent in flour or other powder) is com. bined with bait in a 1:19 ratio by weight so that the final mixture contains anticoagulant at 1:4,000 (about 100 milligrams per pound). On grain baits for ground squirrels, 16 to 24 ounces of warmed lecithin or mineral oil per 19 pounds of bait is used to make the mixture adhere to the grain; mixing is done as described for zinc phosphide baits. Anticoagulant (at 1:16 on oat groats, etc.) can safely be exposed near residences by placing the bait at the middle of a length of 6-inch pipe laid on the ground.

The final mixture is exposed where the squirrels can feed repeatedly so as to obtain the necessary dose. A covered bait box with holes in the sides large enough to admit squirrels readily is satisfactory. 
If placed where squirrels are accustomed to feed and play they will soon discover the grain and commence feeding.

Anticoagulants are no hazard to chickens or turkeys, but dogs and cats will be killed if they feed for several days on the bait or if they repeatedly eat rats killed by the poison. In some situations it may be desirable to surround the bait box with a wire fence of large mesh (hog wire) that will admit squirrels but exclude larger animals and children.

There is little danger to human begins from anticoagulants. If a child or adult eats some prepared bait he should be caused to vomit and a physician called at once. Treatment includes transfusion with whole blood of appropriate type and giving Vitamin $\mathrm{K}$ by mouth or intraven. ously.

Carbon disulfide gas. Ground squirrels and some other rodents can be controlled with poisonous gases. Gases will also kill other animals living in squir- rel burrows, such as skunks, cottontails, burrowing owls, and snakes. The chemicals which have been used include carbon disulfide $\left(\mathrm{CS}_{2}\right.$; often called "carbon"), carbon monoxide ( $\mathrm{CO})$, sulfur dioxide $\left(\mathrm{SO}_{2}\right)$, methyl bromide $\left(\mathrm{CH}_{3} \mathrm{Br}\right)$, hydrocyanic acid $(\mathrm{HCN})$, chloropicrin $\left(\mathrm{CCl}_{3}\right.$. $\left.\mathrm{NO}_{2}\right)$ and tetrachloroethane $\left(\mathrm{C}_{2} \mathrm{H}_{2} \mathrm{Cl}_{4}\right)$.

Carbon disulfide is the gas most widely used for ground-squirrel control. This liquid chemical takes fire and burns readily; it evaporates easily and quickly; and, in the vapor or gas state, it is highly explosive. Stocks of carbon disulfide should be tightly stoppered to prevent loss and should be stored out of doors in a cool, shady place free from fire, sparks, or exposed lights. The fluid corrodes tin cans readily. Carbon disulfide is poisonous to man and to most animals, but it does not readily kill fleas.

Since it is heavier than air, carbon disulfide will settle in the lowest parts of an underground burrow, and will not

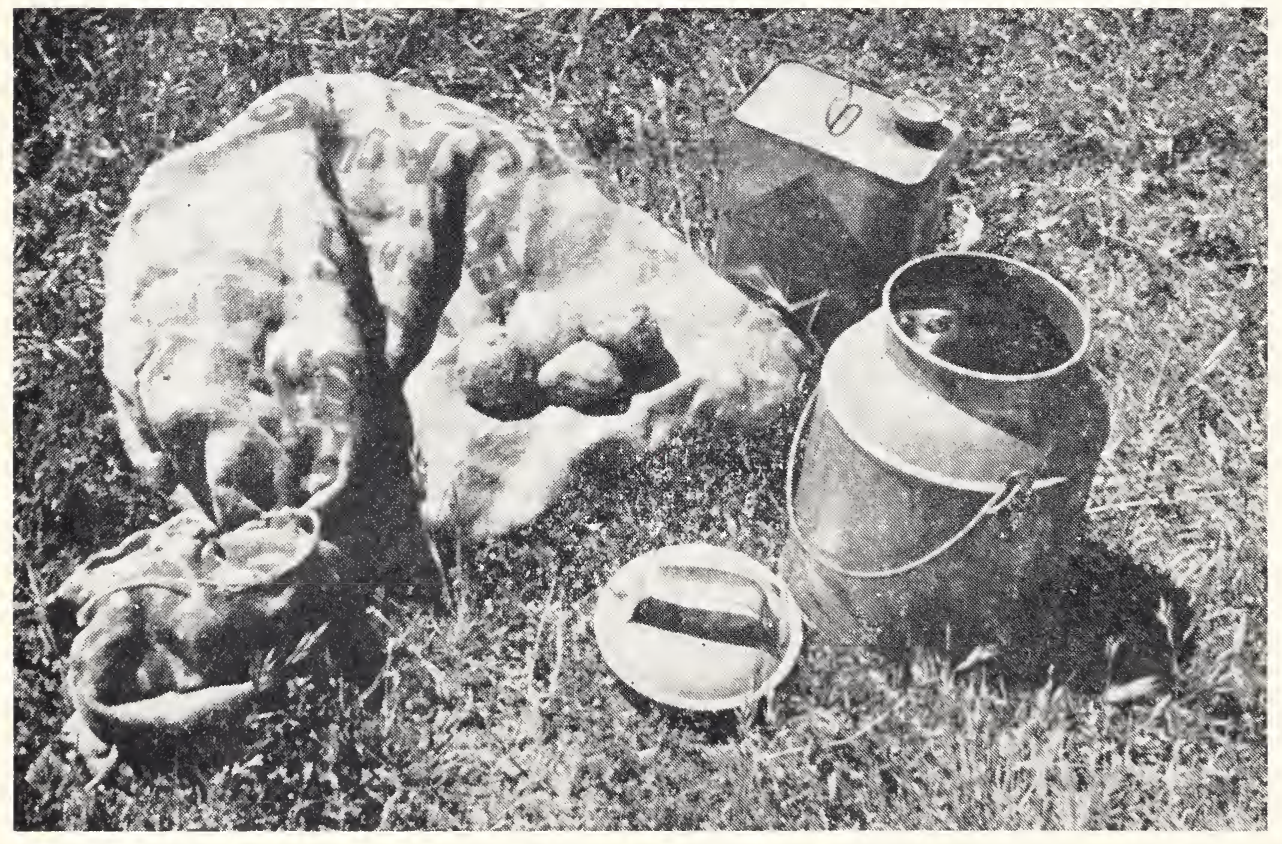

Fig. 15. Equipment for using carbon disulfide in control of ground squirrels: stock can of carbon disulfide, waste balls of jute, and milk can with tight-fitting cover in which waste balls are soaked in the fluid. A stiff wire (not shown) hooked at one end is useful to lift out waste balls and place them in burrows. 
pass higher than the burrow mouth unless forced up with a pump. The fluid vaporizes and spreads more rapidly at high air temperatures, but when it is put into burrows during the warm dry season much gas may be lost through surface cracks in the ground.

Carbon disulfide is applied in two ways: with a special pump to force the fluid or gas into a burrow, or by soaking waste balls in the fluid and then placing them in the burrow. Formerly the gas was ignited a few seconds after the disulfide was pumped into the burrow, but this practice has been given up, for the most part, because it takes longer and is a fire hazard. When conditions permit firing the gas, however, somewhat better control seems to result. Ten or 15 seconds after introducing the gas, a bit of paper or a small kerosene-soaked rag on the end of a stick or a stiff wire, 4 to 5 feet long, is lighted with a match and inserted into the open burrow. The operator stands several feet to one side to avoid being

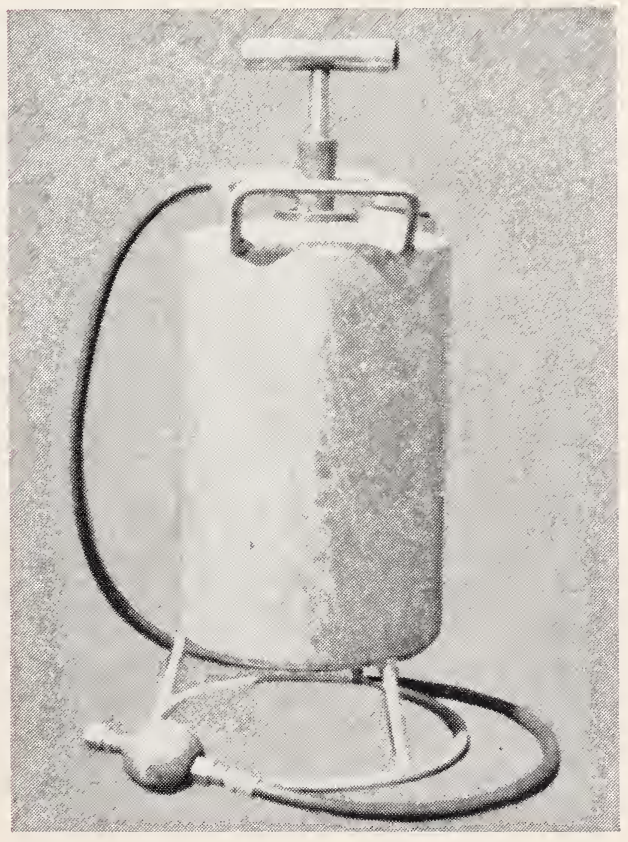

Fig. 16. The Demon Rodent Gun for pumping liquid carbon disulfide into rodent burrows. burned by the explosion from the burrow mouth. Care should be taken not to set fire to nearby grass.

Waste balls about 2 inches in diameter, made of short, frayed strands of jute (from grain sacks), are sold in sacks containing about 1,000 balls. Supplies of waste balls can be bought from some county agricultural commissioners. When only a few are needed, wool trimmings or scraps of cloth can be rolled up and tied to make waste balls.

The balls are soaked in fluid carbon disulfide (fig. 15), and one is placed 15 to 18 inches down each burrow. Each waste ball takes up nearly 2 fluid ounces, and 1 gallon of fluid will saturate up to 70 balls. Before being put into the burrows, the waste balls should be drained for an instant as they are lifted out of fluid. Immediately after a burrow is treated, the entrance should be closed with a shoveful of earth and quickly tramped down; or the entrance may be stuffed tightly with newspaper. Waste balls are especially useful in rocky areas.

Several types of pump have been used in the past to force carbon disulfide vapor into squirrel burrows. The Demon Rodent Gun (fig. 16) has replaced most other pumps. This machine consists of a metal cylinder containing fluid carbon disulfide. The central pump connects to a flexible hose ending in a spray nozzle. The nozzle is placed 15 to 18 inches down the burrow, and the entrance is plugged with a shovelful of earth or a wad of crumpled newspaper to prevent loss of gas. Then a single stroke of the pump forces out 2 ounces of the fluid and vaporizes much of it just inside the burrow. After the hose has been withdrawn, the burrow entrance is closed by trampling the earth or forcing in the newspaper. Some operators use only $1 \frac{1}{2}$-ounce dosages (by partial stroke of the plunger) in the early spring and the full 2 ounces later in the year. Some farmers first go over the area and close all burrows by using mattocks or shovels, then apply 
the gas several days later to those that have been reopened by squirrels. Others consider that this method takes too much time except on clean-up work.

Burrows under trees should be treated only by use of the rodent gun and the gas ignited a few seconds later so none of it remains. W aste balls dripping with carbon disulfide may produce a concentration of the chemical that will injure or kill a tree by absorption through the roots. Some earlier vapor pumps required numerous strokes, but forced carbon disulfide vapor more or less throughout the burrow; the Demon Rodent Gun requires only a single stroke, but tends to leave varying amounts of the liquid close to where the nozzle was inserted and does not force the vapor so far down the bur. row.

Sulfur dioxide gas. Sulfur burned in the presence of air generates sulfur dioxide. Machines to produce and force this gas into squirrel burrows have been built and used by California farmers. One has used a gasoline torch with a sulfur chamber in front of the flame; the draft created by the torch forces the fumes through a nozzle inserted in the burrow. Another type is a cylindrical tank through which air is forced by a hand-driven rotary blower over the burning sulfur; fumes from the sulfur pass into a large hose inserted in the squirrel burrow.

The whitish fumes, besides killing squirrels below ground, will reveal leaks from cracks in the ground surface or from other entrances connected with the same tunnel system. Then the operator can shovel earth to close the leaks. Some users of sulfur dioxide report good results, but others helieve that this gas is not effective enough.

Other gases. Calcium cyanide, in flake or dust form, placed in or pumped into a damp burrow, generates hydrocyanic acid (HCN), a deadly gas rapidly fatal to all forms of animal life. Many years ago, calcium cyanide was tried by official agencies for ground-squirrel control in California, but the results were unsatisfactory.

Another gas fumigant is methyl bromide, used for clean-up on ground squirrels after other methods have been employed (it also kills fleas). It is supplied as a fluid under pressure in heavy steel cylinders or in 1-pound cans. It requires a special release valve and a trained operator to apply and is more expensive than other gases.

Carbon monoxide is contained in the exhaust gases of an automobile, and where field conditions permit driving to the sites of squirrel burrows, a hose from the exhaust pipe may be used to force the gas into the burrows, which should then be closed in. Running the engine for a few seconds forces the gas throughout the burrow. This method has been used under trees where carbon disulfide might dam. age or kill the trees.

Trapping. At any season traps may be used to remove small numbers of squirrels in dooryards, on ditchbanks, or any that escape poison or gas. The wooden box-type gopher trap, with some changes (fig. 17), is useful for this purpose. The back is replaced by $1 / 2$-inch metal straps, half of the trigger loop is removed, and the end is reshaped by bending so the

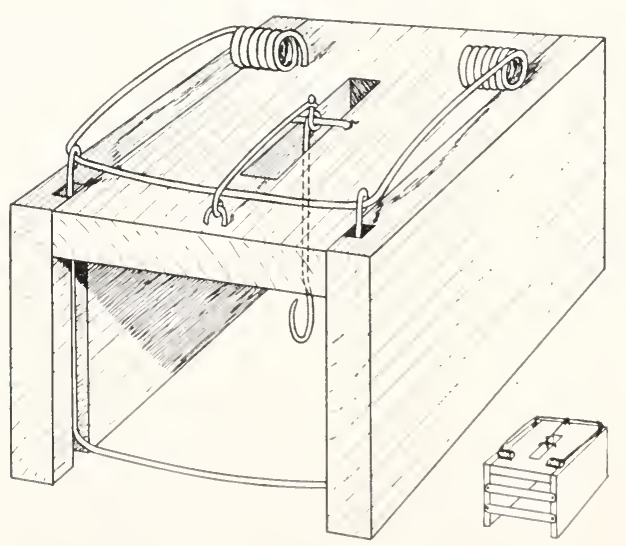

Fig. 17. Trap for graund squirrels (made from wooden pocket gopher trap) as set; smaller figure shows rear of trap. 
bait is held above the ground; also the trigger holding the spring on the top is changed to release when pulled forward. Entire walnuts, citrus fruits, and melon rinds proved effective baits in southern California. Several traps placed within a few feet of one another have completely cleaned out small colonies of squirrels in a few days (Becker, 1940).

This type of trap has the following advantages over the spring steel trap: It can be baited, hence is more attractive to squirrels. It is more selective, catching fewer other animals. It kills the squirrel instantly, and it probably does not leave trap-wise squirrels, such as those which escape from steel traps.

Effective cage traps are made by the Young Trap Company, Havehart Trap Company, and American Trap Company. Squirrels taken in any of these traps should be handled with gloves to prevent fleas from getting on the operator. They may be killed by drowning while still in the traps.

Shooting. Small numbers of squirrels in fields or other open places may be destroyed with a long-range .22 caliber rifle and sometimes with a shotgun.

Natural enemies. Ground squirrels have natural enemies that aid in reducing their numbers. These enemies should be protected and encouraged. They include the coyote, badger, weasel, wildcat, redtailed hawk, golden eagle, rattlesnake, and gopher snake. Badgers, weasels, and snakes capture the squirrels in their burrows. Wildcats and coyctes lie in wait near the burrows until the squirrels come out in search of food. Coyotes and rattlesnakes may not be practical as aids in squirrel control, but the others named are very useful in this capacity.

Observations in San Diego County showed the service of hawks and golden eagles in killing rodents. Four nests (two golden eagle, one red-bellied hawk, and one red-tailed hawk) with young contained a total of 14 ground squirrels, 9 jack rabbits, and 2 pocket gophers. The dead rodents were surplus which the old birds had carried to their young, in addition to food eaten on the days of observation. Hawks and eagles may, therefore, kill more rodent prey than they and their young can eat.

Large predatory birds are important aids in rodent control; they work every day in the year and without expense to man. An occasional hawk may take chickens, but most of them are entirely beneficial and in California are fully protected by law

Other methods. Small isolated orchards of deciduous fruits or nuts may be protected from ground squirrels by smooth cylinders of tin fastened about the tree trunks. This tinning, if started about 2 feet above the ground and continued upward for 2 or 3 feet, will keep the ground squirrels out of the trees unless there are drooping branches on which they can climb.

Flat disks of sheet metal about 2 feet in diameter are often used to protect leaves of young roadside trees from being eaten by ground squirrels. A hole in the center of each shield admits the trunk of the tree; and a radial cut, from circumference to center, enables the shield to be placed in position, below the first branches.

Seed corn can be treated with coal tar to protect it from ground squirrels during germination. For this purpose, 1 tablespoon of coal tar is added to a gallon of boiling water. When the mixture has cooled, the corn is stirred in and allowed to remain several minutes; germinating qualities will not be impaired.

\section{Costs of Control}

The amount of infestation, the method used, the current prices for labor, the speed and skill of laborers, and the kind of area treated all affect the cost of control. Large-scale operations on flat lands are less expensive per acre than those on small land units or in rough foothills with brush and rocks. Variations in the prices 
of materials and in the cost and quality of labor make it impossible to give costs per acre.

Some recent prices (1964) for materials were: alkaloid strychnine, $\$ 2.00$ per ounce; strychnine-coated grain, 12 cents per pound; zinc phosphide, $\$ 5.00$ per pound; Pival $\mathbb{R}$ ( 0.5 per cent), 95 cents per pound; warfarin ( 0.5 per cent). $\$ 1.95$ per pound; carbon disulfide, $\$ 1.75$ per gallon; waste balls, 1 cent each; methyl bromide, $\$ 1.00$ per pound.

\section{OTHER GROUND SQUIRRELS, in northern California, may damage alfalfa, pasture, and grain}

The Oregon ground squirrel (Citellus beldingi) inhabits most of Lassen, Modoc, and eastern Siskiyou counties and the high Sierra Nevada south to Fresno and Inyo counties. It is of stocky build (fig. 18 ), with a short tail and plain brownishgray coloration. The head and body are about $81 / 2$ inches long, and the tail is about $2 \frac{1}{2}$ inches. The animal is mainly an inhabitant of grasslands, and almost never climbs. It sits bolt upright when alerted, hence is often called "picket pin." It has a shrill trilling whistle that carries for a long distance.

\section{Habits}

The burrows resemble those of other ground squirrels but are smaller and not so deep. The food is chiefly grasses, pas- ture vegetation, and the leaves and stems of alfalfa and grain. Most Oregon ground squirrels emerge from hibernation by mid-March or earlier, even when there is still much snow on the ground, and hole up in July or later. The average litter is about eight, and the young appear from mid-May at the lower altitudes $(3,000$ feet) until early June at higher levels.

\section{Control}

The Oregon ground squirrel may be controlled by poisoned oats (formula 5) or poisoned dandelion greens.

The poisoned grain should be scattered by hand or with a spoon on hard bare ground, or along and near squirrel runways. It is less likely to be found and eaten if dropped in tall grass or on the

\section{S}

FORMULA 5

\section{For Oregon Ground Squirrel}

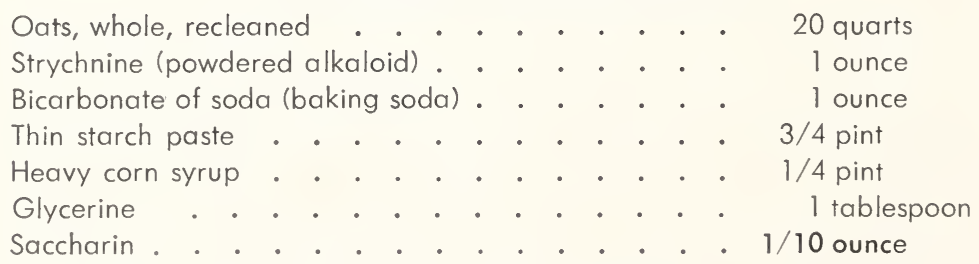

Mix the strychnine, baking soda, and saccharin together dry. Prepare the starch paste by mixing 1 heaping tablespoon of dry gloss starch in a little cold water until smooth. Then pour into $3 / 4$ pint of hot water, boil and stir until clear. Add the dry strychnine, soda, and saccharin, then the corn syrup and glycerine; stir thoroughly. Pour the hot mixture over the oats, turning and stirring until each kernel is coated. Spread the coated grain out in a thin layer until the coating is thoroughly dried. Then store in a can or sack, properly labeled as POISON, until used.

\section{See Page 6-General Precautions with Poisons}




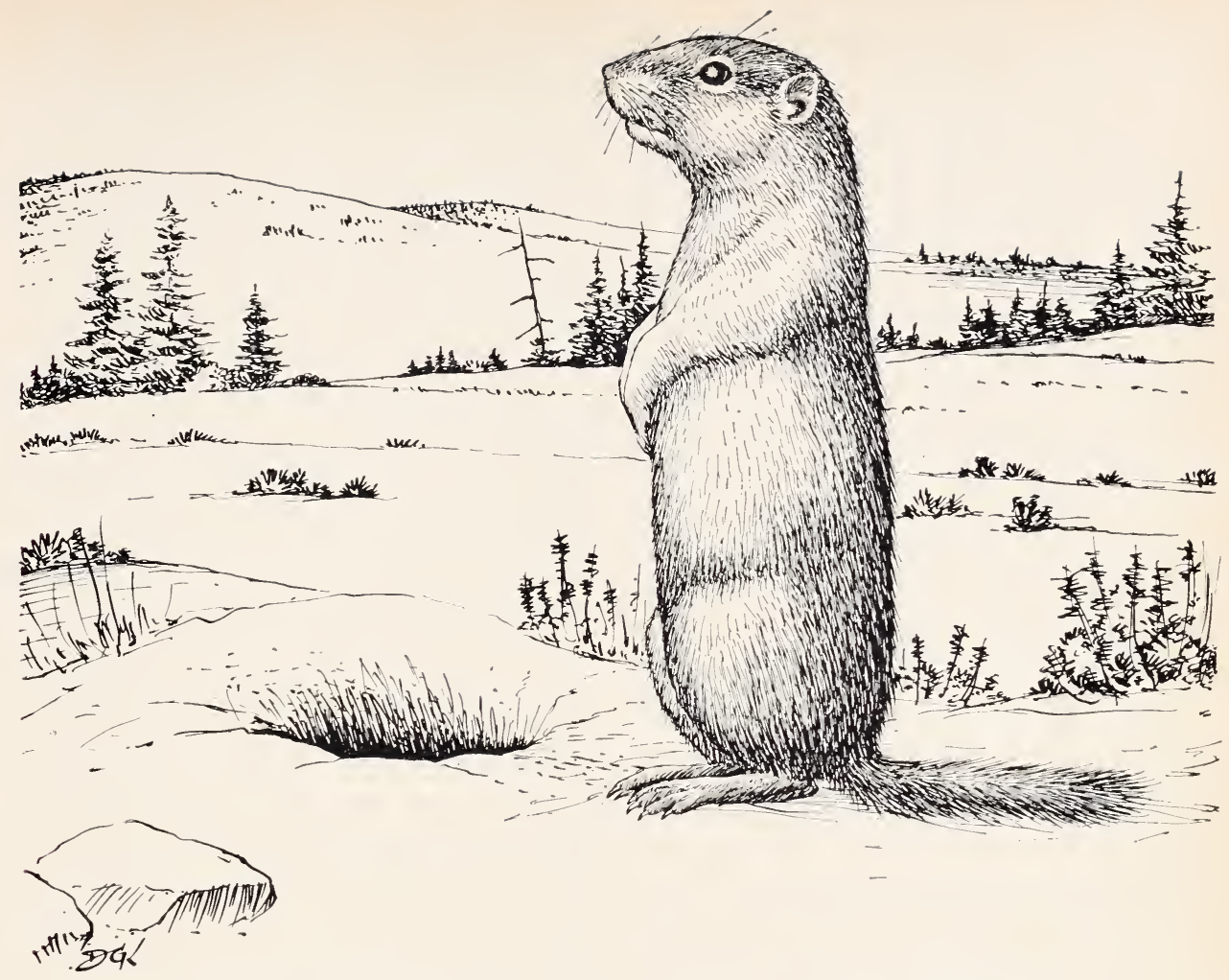

Fig. 18. Oregon or Belding ground squirrel of northeastern California. Head and body about $8 \frac{1}{2}$ inches, tail, $2 \frac{1}{2} 2$ inches.

soft earth around burrows. About 1 tablespoon should be scattered at each spot to cover 1 to 2 square feet; 1 quart provides 30 to 35 baits.

For poisoned dandelion greens, use formula 5 but substitute 5 gallons (bulk) of freshly cut green dandelion plants with roots, or fresh chicory, for the oats. Water cress or alfalfa leaves are less satisfac. tory. Two or three pieces of greens are put into each burrow; this does not endanger birds.

Carbon disulfide may be used to gas burrows of this squirrel as described for the California ground squirrel.

Around mountain cabins and in some localities in eastern California and the deserts it sometimes becomes necessary to control other species of ground squirrels, and also chipmunks. In this group are the golden-mantled ground squirrel (Citellus lateralis), the antelope ground squirrel or chipmunk (Citellus leucurus), and the small striped chipmunks (Eutamias). The general methods described for control of the California ground squirrel (pages 27-33) will usually prove satistfactory.

To rid a small area of a few squirrels, as about a mountain cabin, the animals may be shot or trapped. Ordinary wooden rat traps can be used, but care must be taken, when removing dead animals, to see that fleas or ticks from them do not get on the operator as they can carry infectious diseases from diseased animals to man. Gloves should be worn, and clothing should be treated immediately afterward with fly spray. Poisoned bait should be used only when it can be placed on the ground, under shelter of boards or logs, where birds or pets cannot reach it. Anticoagulant bait may be of value in such places. 


\section{TREE SQUIRRELS-The Gray Squirrel and the Eastern Fox Squirrel sometimes raid fruit or nut trees}

In the foothills and mountains of California there are two kinds of native treeinhabiting squirrels active during the daytime: the gray squirrel (Sciurus griseus) and the chickaree (T'amiasciurus douglasi). also called red or pine squirrel. The head and body of the gray squirrel measure about 10 to $11 \frac{1}{2}$ inches, with the tail nearly as long; the coat above is light steel gray in color, with the under surface of the body and margin of the tail white. The chickaree is smaller, $71 / 2$ to $81 / 4$ inches, with the tail $4 \frac{1}{2}$ to $51 / 2$ inches long. Its coat is dark brown above with a reddish tinge on the back, and a black line along either side borders the white or buff belly. The tail is blackish with white-tipped margins.

The gray squirrel sometimes lives near nut and fruit trees and may raid them. A grower in Santa Cruz County reported that in years of short acorn crops the gray squirrels took many English walnuts and also gnawed into boxes of apples stored in the open. He captured several squirrels in box traps, transported them less than a mile from his ranch, and released them; no further damage was noted. Tin guards, like those described for ground squirrels, would exclude tree squirrels as well, provided there were no low-hanging branches on the trees and also that the trees were sufficiently far apart so that the gray squirrels could not travel overhead from tree to tree.
Chickarees should be kept out of mountain residences because some have proved to carry diseases transmissible to man.

Open seasons for hunting tree squirrels have been declared in recent years by the Department of Fish and Game for certain districts or parts of districts. These may change from year to year; some local open seasons have been established where damage by tree squirrels was occurring. If a farmer experiences damage in a place where there is no open season, he should ask the local game warden for a permit for control by shooting.

A brownish fox squirrel (Sciurus niger rufiventer) from the eastern states has been introduced and become established in several parts of California. It is grizzled brown above and rusty colored below, and is nearly the size of a gray squirrel. In the wahnut orchards of the San Fernando Valley it is now sufficiently abundant to require annual control. Damage also is done to oranges and avocados. and lead-covered telephone cables are cut by these squirrels.

Control is by use of a No. 0 steel trap placed on a squirrel path or with the box trap used for ground squirrels (fig. 17). A baited trap placed beside a wooden fence and sheltered under a leaning board has been successful. Meat, rather than nut meats or grain. is often a better bait. Shooting, under permit, also has sometimes been used.

\section{For more information ...}

Additional material on ground squirrels may be found in the following references: Becker, E. M.

1940. An effective ground squirrel trap. California State Dept. Agr. Bul. 29: 152. 1 fig.

Berry, C. E.

1938. Methyl bromide as a rodenticide. California State Dept. Agr. Bul. 27: 172 80. 5 figs. 
Burnett, W. L.

1932. The action of strychnine on the Wyoming ground squirrel Citellus elegans. Colorado Agr. Exp. Sta. Bul. 384: 1-19.

Fitch, H. S.

1948. Ecology of the California ground squirrel on grazing lands. Amer. Midland Naturalist 39: 513-96.

Grinnell, Joseph, and Joseph Dixon

1918. Natural history of the ground squirrels of California. California State Comm. Hort. Monthly Bul. 7: 597-708. 5 pls. 30 figs. (Out of print.)

Howell, A. H.

1938. Revision of the North American ground squirrels. U. S. Dept. Agr., Bur. Biol. Survey, North American Fauna 56: 1-256. 32 pls. 20 figs.

Jacobsen, W. C.

1923. Rate of reproduction in Citellus beecheyi. Jour. Mammalogy 4: 58.

Storer, T. I.

1930. Summer and autumn breeding of the California ground squirrel. Jour. Mammalogy 11 : 235-37.

Storer, T. I., and R. L. Usinger

1963. Sierra Nevada Natural History. Berkeley, University of California Press. $7+374$ pp., 24 col. pls., 65 pls., 24 figs.

Tomich, P. Quentin

1962. The annual cycle of the California ground squirrel, Citellus beecheyi, Univ. California Publ. Zool. 65: 213-282, 23 figs. 


\section{Meadow Mice, Kangaroo Rats, and Muskrats, damage farms and gardens in many places}

\section{Meadow Mice}

Meadow mice or voles (genus Microtus; fig. 19), commonly called field mice, are blunt-nosed, with small furry ears and a scantily haired tail, and are covered with soft dense fur that is blackish brown or grayish brown. Adults measure 4 to 6 inches in head-and-body length, with the tail $13 / 4$ to $23 / 4$ inches long. They live in fields or in ditchbanks covered with weeds or grass, in meadows, in grain or alfalfa fields, sometimes around haystacks, and in orchards with covercrops or where the grassy ground cover is allowed to remain. Meadow mice live both on the surface of the ground and in burrows. Most species cut off the vegetation to form little pathways about an inch in breadth that extend here and there through the grassland. These connect with the many small bur- rows which the mice make in the soil (fig. 20). Such workings are often hidden when the grass cover is tall. If the presence of meadow mice is suspected, it may be necessary to part the grass tops and search beneath the cover. The number of mice present may be inferred by the amounts of freshly cut grass or of droppings to be seen in the runways.

Meadow mice cut alfalfa and grass in irrigated pastures, often hollow out overwintering sugar beets, sometimes damage strawberry and artichoke plants, and consume hay in stacks or in bales left in the fields, gnaw the bark and roots of trees surrounded by grass and weeds, and eat root crops or bulbs. Alfalfa fields are occasionally damaged by meadow mice to the stage where no profit results to the farmer. The damage is irregular in

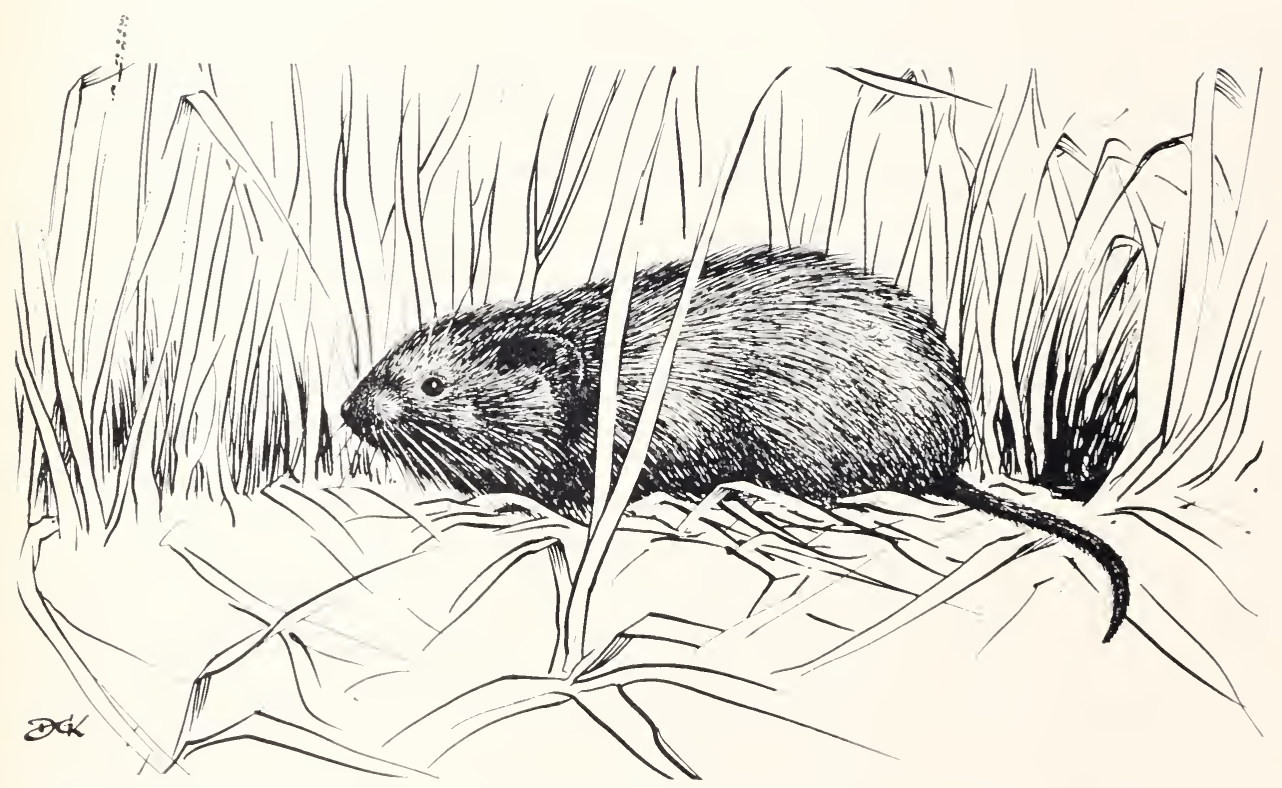

Fig. 19. Meadow mouse. The fur is dense and soft, blackish to grayish brown, and the ears are furry and partly hidden. Head and body length, 4 to 6 inches, tail $13 / 4$ to $23 / 4$ inches. 
amount, season, and place of occurrence. Periodic increases in meadow mice have been noted at certain places in California. They have increased greatly in some recent years on farms near Tule Lake (Siskiyou County), in the delta region of Sacramento and San Joaquin counties, and locally elsewhere. In the 1957-58 outbreak at Tule Lake, fields were completely stripped of crops and riddled with burrows. Many of the mice were infected with tularemia (Murray, 1965).

Preventive treatment, where it can be used, consists of clean cultivation. Orchards with cover crops should be watched for signs of damage by meadow mice, and steps taken at once to control them if necessary. Otherwise, clean cultivation in orchards and the removal of grass and weeds along fences, about farm buildings, and around piles of lumber will reduce the shelter and food for these animals.

Control methods. For a small area or a few mice the best plan is to use mousetraps baited with oatmeal, rolled oats, or bits of apple or carrot or other root vegetables, and set with the triggers of the traps across the runways. The traps will then be effective on mice running in either direction; sometimes unbaited traps will serve. Traps should be visited at frequent intervals, since these mice are active by day as well as at night and trap efficiency is increased by frequent attention.

When meadow mice are present in large numbers or over a large acreage, it is necessary to use poison. Formerly strychnine on alfalfa leaves was employed (formula 7), but recently zinc phosphide or rolled barley or oats or oat groats (formula 6) has been used.

The poisoned bait-either grain or alfalfa-is broadcast by hand (gloves should be worn) so that it will scatter on the runways and be found by the mice. For heavy mouse infestations, amounts

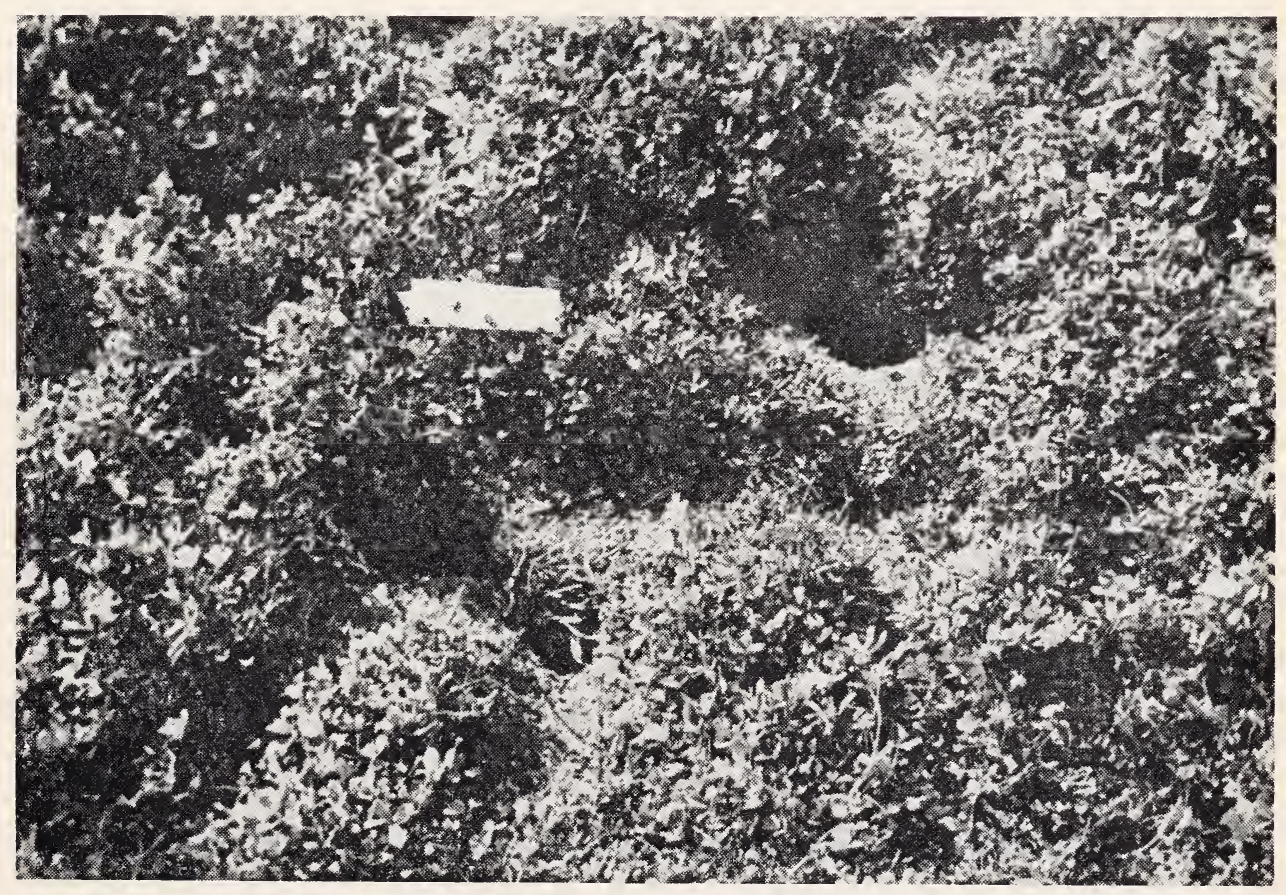

Fig. 20. Burrows and runways of meadow mice in an alfalfa field heavily infested with these rodents. The mice kill many plants by cutting the roots and eating the stems and leaves. 


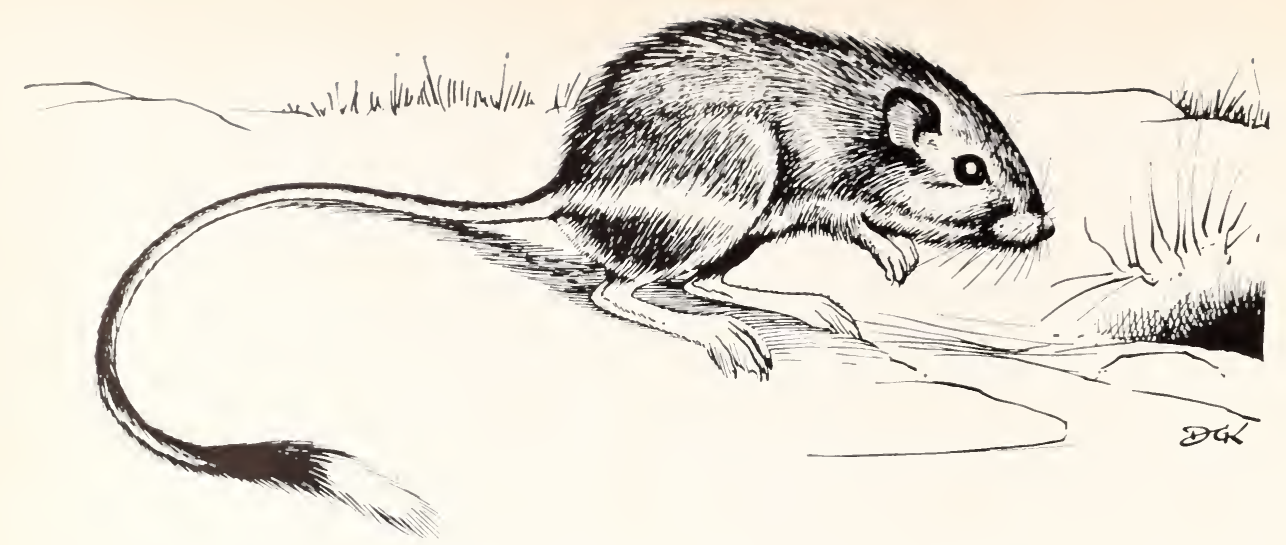

Fig. 21. Kangaroo rat. At either side of the mouth is a fur-lined pouch. The body is brown or tan above, pure white below; head and body about 4 inches, tail about $71 / 2$ inches long.

up to 15 pounds of grain lait are used per acre. One man can treat 15 acres a day, walking back and forth across the field and using marker stakes along the field borders to cover the field adequately and evenly. Repeated treatments may be necessary when the mouse population is large.

In orchards with permanent cover crops where trees are being damaged by meadow mice, anticoagulant baits cast in blocks of paraffin have reduced dam. age. The warfarin or Pival ${ }^{\circledR}$ and grain (in 1:19 ratio) is stirred into melted paraffin to yield a thick but flowable mixture that is poured into paper cups or cardboard milk cartons. Blocks of halfpound weight are placed at the bases of trees (Marsh and Plesse, 1960).

Chemical sprays (toxaphene, endrin, and possibly others) have been applied to fields damaged by meadow mice in efforts at control. The hazards to spray operators and later to people or livestock using crops so sprayed are such that these materials must not be used for control.

\section{Kangaroo Rats}

In lowland localities, where dry farming is practiced adjacent to wild land of desert or semidesert character, kangaroo rats (genus Dipodomys) may damage grain crops. These distinctive rodents (fig. 21) have long hind legs and feet, short small forefeet, long tufted tails, brown or tan backs, pure white underparts, and a pair of external fur-lined cheek pouches like those of pocket gophers). The head and body are about 4 inches long and the tail about $71 / 2$ inches. Kangaroo rats live in short shallow burrows, in sandy or soft ground. Burrow entrances are usually closed with earth during the day. There may be considerable fluctuation in their numbers. Over much of interior California these rodents are of slight importance, having been exterminated from many areas long under cultivation. When necessary, they may be easily controlled by use of strych. nine-coated barley (formula 2, p. 28) broadcast by hand near the burrows as is done for ground squirrels.

\section{Muskrats}

The muskrat (Ondatra zibethica) is a large aquatic rodent having a scaly, scantily haired tail and dense, darkbrown fur (fig. 22). The head and body measure $91 / 2$ to 12 inches, and the tail is $71 / 2$ to 10 inches long. Muskrats live along marshy borders of lakes, streams, and irrigation ditches, making large burrows with underwater entrances in the hanks. and sometimes build small 


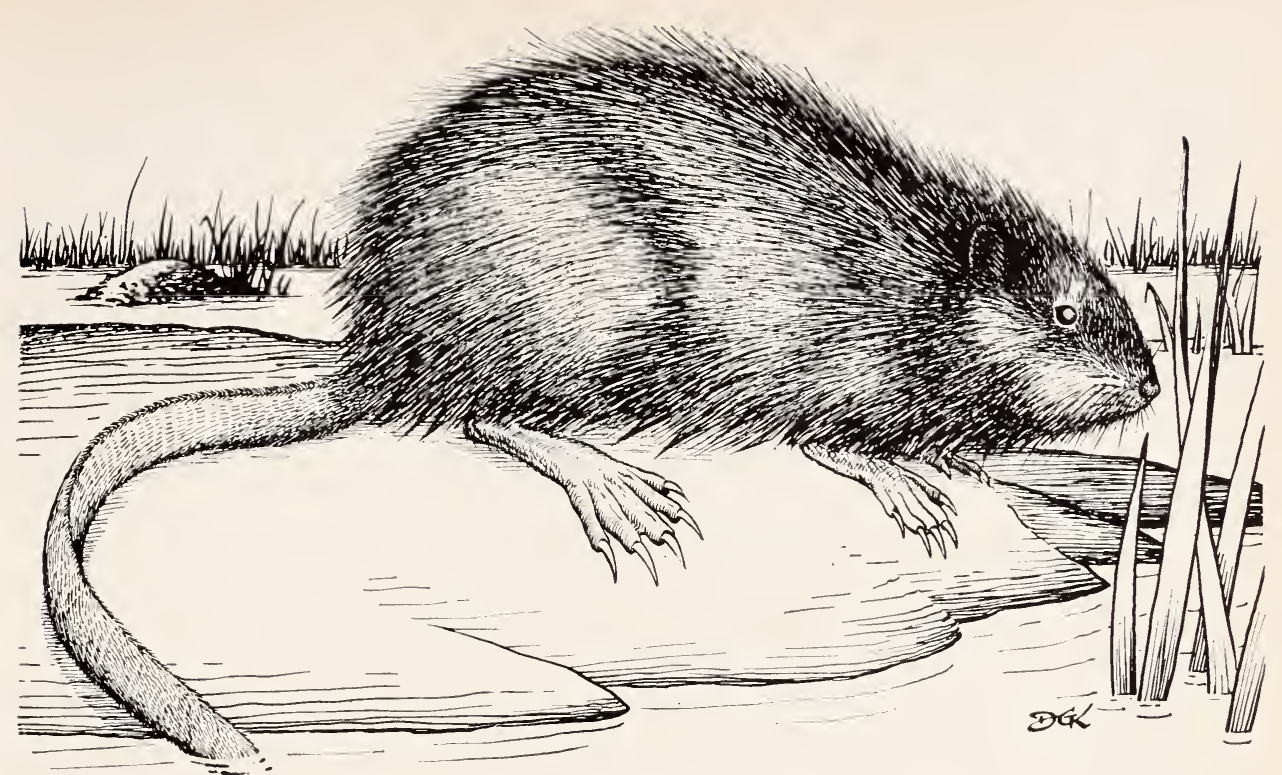

Fig. 22. Muskrat. The tail is narrow, higher than wide, and scaly; the fur is soft, dense, and brownish. Head and body $91 \frac{1}{2}$ to 12 inches, tail $7 \frac{1}{2}$ to 10 inches.

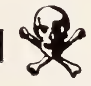

FORMULA 6

For Meadow Mice

Oats or barley, lightly rolled . . . . . . . 100 pounds

Zinc phosphide, powdered. . . . . . . . 16 ounces

Mineral oil with lecithin, or corn oil . . . . . . . 22 ounces

The cereals named are the most satisfactory but others have been used at times. Change the kind of bait if possible in repeat treatments. Corn oil is best to make the zinc phosphide adhere to the bait. When using mineral oil it is necessary to experiment and determine the amount necessary.

Warm the mineral oil and stir in the zinc phosphide until evenly mixed. Pour this mixture, a little at a time, over the grain, stirring vigorously and continuously until all kernels are evenly coated with the blackish zinc phosphide.

A batch of 10 to 20 pounds may be made in a large bucket or pan stirring with a wooden paddle or large spoon. Larger amounts are best mixed in a steel or wooden drum (or clean cement mixer) with inside baffle plates and mounted on a shaft at an angle so that it can be turned easily. The drum should be revolved long enough to ensure even coating of all the grain.

Workers should wear gloves and do the mixing outdoors or in a well-ventilated room; and they must avoid breathing fumes from the poison mixture.

\section{FORMULA 7 \\ For Meadow Mice}

Green alfalfa leaves

100 pounds

Strychnine alkaloid, powdered .. . . . . . 3 to 4 ounces

Dissolve the strychnine in 2 quarts of water; sprinkle over the bait, turning the latter until all parts are moistened.

See page 6-General Precautions with Poisons 
"houses" of plant materials in quiet waters. They eat underwater roots of cattails and other aquatic plants together with some green vegetation. Muskrats breed through much of the year and commonly have five to seven young per litter.

Muskrats are native to much of North America from the Gulf States to Alaska but originally in California lived only in a few places on the eastern border. They invaded the Imperial Valley when canals were built to carry water from the Colorado River. During the 1930's muskrats escaped from fur farms or were released in several localities from Del Norte and Shasta counties south to Kern and Santa Barbara counties (Storer, 1937; Twinning and Hensley, 1943). In the coastal counties, there are now a few in scattered localities. But in parts of Modoc County, throughout the Sacramento Valley and Delta region, and in the San Joaquin Valley south to Fresno County they have multiplied to become an agricultural pest in irrigation canals.

The "rats" burrow commonly in ditch banks, levees, and dams, and about head gates or outlet boxes, resulting in breaks in the earth banks with consequent loss of water. Farmers experience trouble and expense to detect and repair the damage, besides suffering some loss in crops, especially of rice in small fields. Rice growers may experience premature drainage of producing fields by undetected leaks. The total annual damage in the Sacramento Valley amounts to thousands of dollars.

Fur trappers take sulstantial numbers of muskrats for pelts, but naturally seek muskrats where abundant and in winter when the fur is prime, so their efforts are only of limited value in reducing the animals on farms. In 1956-57 trappers took about 73,800 , sold at 69 to 96 cents per pelt-about two-thirds the total income from furs in California.

Muskrat sign. Evidence of the animals includes: (1) live individuals swimming by day where unmolested; (2) tracks of the broadly spread hind feet and tail streaks on muddy shores; (3) large droppings at the shore or in water; (4) floating pieces of cattail leaves where muskrats have been feeding; (5) relics of cattail roots at feeding stations; (6) remains of crayfish shells near burrows; (7) burrow entrances just below the edge of the water; and (8) cave-ins of burrows in banks where livestock or people have stepped and collapsed part of a tunnel. Entrance holes commonly are near clumps of cattails or tules or beneath a mound of sod on a bank; often there are several close together connected by a tunnel parallel to the bank.

Crayfish often make rather large burrows at the water's edge, but unlike muskrat tunnels these usually lead straight downward and are perfectly round. Norway rat burrows are smaller than those of muskrats and ordinarily dug above the water margin. Damage to corn, sugar beets, or other crops growing near ditches is more often due to Norway rats than muskrats.

Trapping. Muskrats are relatively easy to take in No. 1 steel traps placed at the burrow entrance in about 2 inches of water. The end of the trap chain should be tied to or put over a slender stake in the water so the trapped muskrat can swim away from the bank; the weight of the trap will pull the animal under water so it soon drowns. Many trappers use no bait; others suspend a piece of parsnip, carrot, sweet potato, or other root vegetable on a slender stick about a foot over the trap. Soil in the bank slightly disturbed with a trowel may serve to attract a muskrat to the trap site.

Winter trapping for fur should be encouraged because it serves to remove a part of the muskrat population. Fur trappers, however, change location as necessary to obtain a maximum catch; they seldom remain in one place long enough to reduce the animals to low numbers. For agricultural protection it sometimes is necessary to employ paid and super- 
vised trappers at other seasons to keep down the muskrat population.

Poisoning. Baits must be placed where available to muskrats and not to other animals or birds. A floating bait box (fig. 23), anchored near burrows, will offer bait only to muskrats or houserats. For stability the box should be about the dimensions shown, supported on $4 \times 4$ inch redwood floats (preferably painted); sealed metal tanks also will serve as floats. It is desirable to keep the bottom of the box above the water so it will be dry. The box provides a roof to exclude other animals, a landing platform, and corner troughs for bait.

Various grain, fruit, and vegetable baits have proved acceptable but rolled barley or rolled wheat poisoned with an anticoagulant-warfarin or Pival ${ }^{\circledR}$ (in a
19:1 ratio of bait to poison) - is acceptable and effective. Bait boxes should be examined and cleaned daily, with replenishment of bait, until muskrats no longer are visiting. Anticoagulant baits of rolled barley cast in paraffin blocks, as described for meadow mice, have been tried. Each is cast on a slender pointed stick by which the bait is fixed in a place where muskrats travel. Baits with zinc phosphide and strychnine have been tried but gave poor results; any muskrats that survive the initial treatment will be bait-shy. This does not result with anticoagulant bait.

Gassing. Near Bakersfield muskrats were controlled by pumping carbon disulfide gas into burrows at a season when water had been withdrawn from the canals and ditches and the tunnels were easily found.

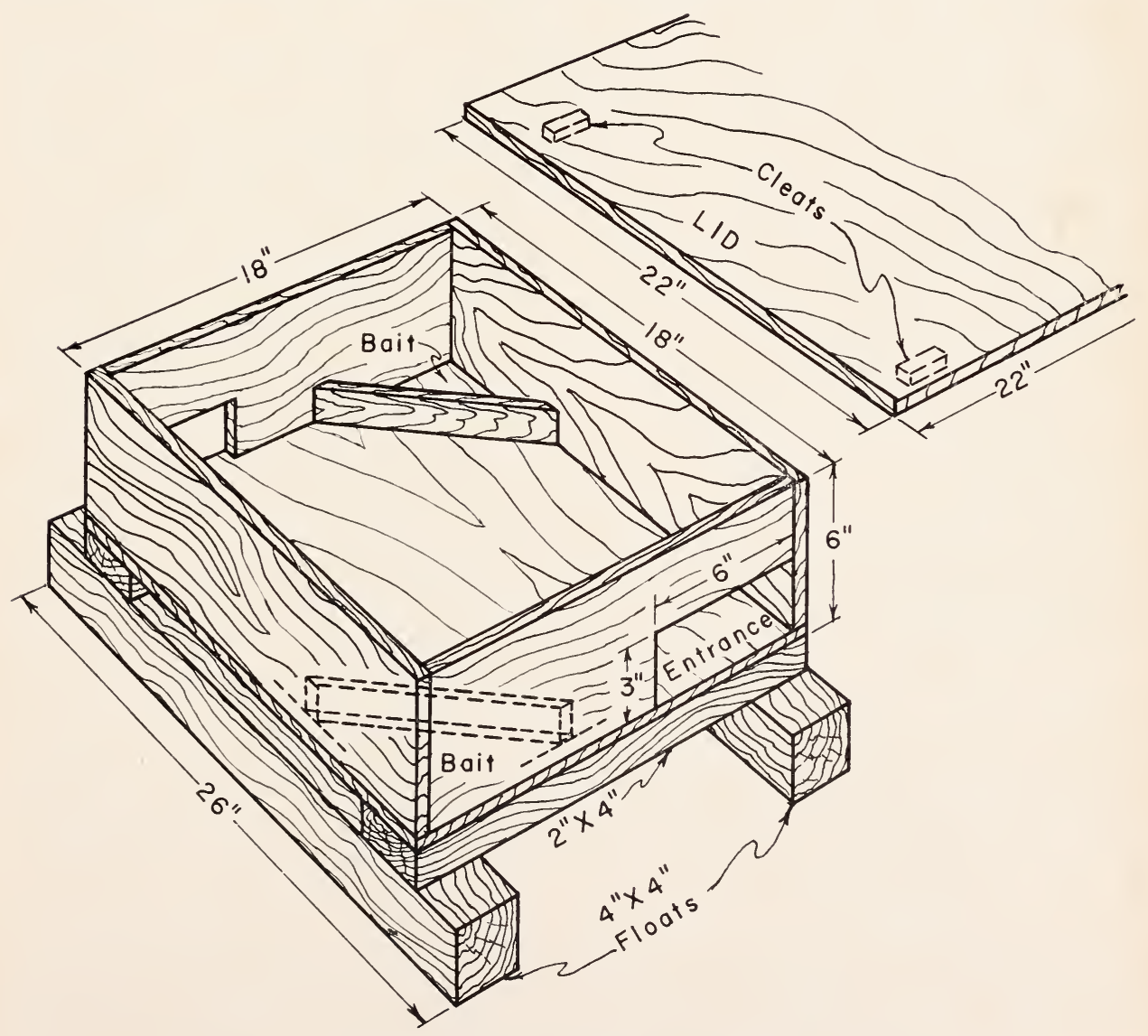

Fig. 23. Floating bait box for muskrats. 
Other control methods. If levees or check banks can be enlarged to a width of 6 feet at the base there will be less erosion damage by muskrat burrowing. In new levees a central core of coarse gravel will keep the rodents from burrowing through. Grazing cattle or sheep on levees will both reduce weed cover (chemical weed control also may be used) ; the livestock help to cave in any burrows near the surface-and discourage muskrats. Whenever an occupied burrow is found the muskrat should first be destroyed by trapping; then the burrow should be broken in with a crowbar as completely as possible and the soil firmed down by trampling.

Large check boxes with lateral wings, firmly set with no spaces beneath will reduce muskrat damage. A recommended size is 24 inches wide, 48 inches long, 18 inches higl, with 24-inch wings. all of 2-inch lumber. Further means to deter burrowing at head gates and other vulnerable spots include:

(1) lining the ditch surfaces with a 48-inch width of 2-inch, no. 14, diamond mesh wire; it should be placed with 24 inches above and the same width below the water and should extend about 15 feet on either side of the check box.

(2) an apron of concrete lining the ditch for 15 feet in either direction from the head gate.

(3) impregnating the soil with discarded crankcase oil as a repellent. With a l-inch crowhar make a series of holes at 4 -inch intervals for 12 to 15 feet each side of the head gate, parallel to the water margin. Each hole should extend from about 6 inches ahove high water level to the same distance below the low water line. Fill each hole within about 3 inches of the surface with oil and cap with soil.

\section{Coypu}

The coypu or nutria (Myocastor coypus), a large semiaquatic rodent of South America, has eseaped from fur farms in California and several other states. The animal somewhat resembles a muskrat, the head and body being about 8 inches long and the tail 16 inches (but round, not vertically compressed as in the muskrat). The body is densely covered with dark yellowish or reddish brown fur and the feet are webbed. The large incisor teeth are orange colored.

Copyus inhabit marshy ponds, ditches, and canals, eating many kinds of aquatic plants, including waterfowl foods and young rice; they will attack row crops growing near water. In cattail marshes they build feeding platforms on dead aquatic vegetation. For nesting shelter a tunnel 8 to 10 inches in diameter and up to 20 in length is dug in a bank. often so close to the surface that cattle may break in the burrows. Two or more litters of four or five young may be produced annually.

Attempts at rearing coypu for fur have heen made in many places. In California a permit is required from the State De. partment of Agriculture and the animals must be in escape-proof pens (Calif. Agric. Code. Sees. 165-166). Despite these requirements, coypus have escaped in many localities in western United States. In the 1940's some were out in marshes of Stanislaus County where 18 were trapped. Shooting and trapping are approved methods of control. Coypu are too large and heavy to use the floating bait boxes here recommended for muskrats. Anyone who sees, or who finds evidence of, these animals wild in California should notify the nearest county agricultural commissioner. 


\section{RABBITS}

\section{RABBITS damage or destroy crops and trees. Control measures are limited because some rabbits are protected as game}

Rabbits (fig. 24) comprise two major types: the hares (genus Lepus), represented by the jack rabbits and the snowshoe rabbits that live entirely aboveground, make no nests, and bring forth their young fully covered with fur, with their eyes open, and able to move about at once; and the true rabbits, including the cottontail and brush rabbits (genus Sylvilagus), that dwell in dense cover, under stone piles and brush, or in burrows, and leave their young in the nest for a period of growth (Orr, 1940).

Black-tailed jack rabbits (Lepus californicus) occupy the lowland, foothill, and desert portions of California, but are sparsely represented in the humid coast region. They are absent from the higher mountains above the yellow-pine belt, but present in the northeastern pla-

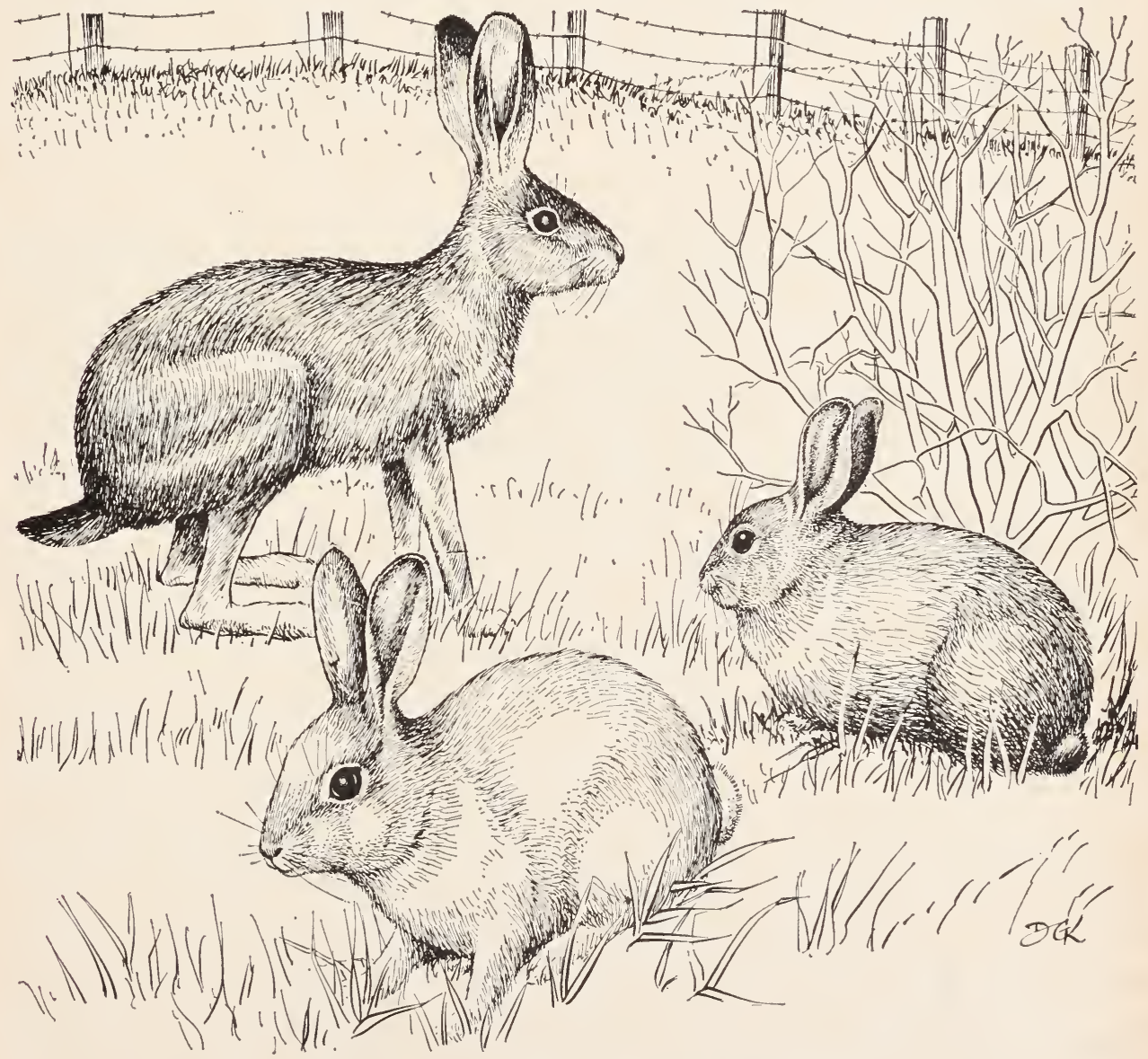

Fig. 24. Common California rabbits. Left, black-tailed jack rabbit that lives in open country; head and body 18 to 20 inches, ears about 6 inches long. Center, cottontail, common in streamside thickets and pastures; length about 13 inches, ears 3 inches long. Right, brush rabbit, found close to bushes and chaparral in the foothills; length about 11 inches, ears $23 / 4$ inches long. 
Ieau counties. They depend upon speed and dodging to escape enemies. They live chiefly in open places, seldom inhabiting dense brush or thick woods. Females may produce more than one brood a year, especially on irrigated land. The number of embryos varies from three to eight, and the average litter is about four; young are in evidence through much of the year, but the greater number are produced in the spring months.

Jack rabbits make no nests, but individuals often have a more or less regular retreat or "form" beneath a bush, where the animal is somewhat sheltered from the full heat of midday sun and yet can watch for the approach of enemies.

Their food includes a wide variety of plants, both wild and cultivated, the latter including grain, alfalfa, various truck and field crops, and at times the bark and tender shoots of small orchard trees. Indeed, one of the commonest complaints is of the difficulty in getting new orchards or vineyards started on areas adjacent to lands where jack rabbits are common.

Formerly jack rabbits were enormously plentiful, especially in the San Joaquin Valley and on the flatter areas of southern California. Many spectacular rabbit drives were held; most of the people of a district would turn out and surround a territory several miles in extent, driving the rabbits toward a central corral bordered by wing fences. After being concentrated in such an enclosure, the rabbits were clubbed to death by the hundreds and even thousands.

Drives and other measures have reduced the population far below the earlier numbers, yet there are still enough jack rabbits in some places to do considerable damage to the more intensive agriculture of the present day. Their numbers vary considerably from year to year. Farmers should watch these animals on their land, because, in years when they are abundant, crop damage may be severe. Overgrazed lands tend to have larger jack rabbit populations than areas on which the grass cover is higher. Black-tailed jack rabbits are not protected by law and may be destroyed at any time of year.

Snowshoe rabbits live in the higher parts of the Sierra Nevada and in the northeastern plateau region of California. There are two kinds adapted to living on or in the snow during the winter months: the large white-tailed jack rabbit or Sierra hare (Lepus townsendi) and the smaller snowshoe rabbit ( $L$. americanus); both are hares. These, like the black-tailed jack rabbits, are surface dwellers. Their feet being densely covered with long fur, they can travel readily on snow. The tail of the snow-inhabiting rabbits is always white, and the animals themselves are white in winter. These animals live where there is little intensive agriculture; they occasionally nibble the twigs and bark of apple trees during the winter months, and the snowshoe rabbit damages young forest trees.

Cottontail and brush rabbits are true rabbits occurring over the lower altitudes in California. Cottontails (Sylvilagus audubonii and $S$. nuttallii) are more common in stream-side thickets and pastures; brush rabbits (S. bachmani) inhabit brushy and chaparral-covered slopes in the hills. Little is known about their rate of increase or manner of caring for the young. The litters are small, averaging about four, and are usually produced in the spring months. Both of these rabbits will feed upon cultivated crops of garden and field.

These rabbits are classed as game and, over most of California, may be hunted only between September 1 and Decem. ber 31. Owners or tenants of land and/or their agents, authorized in writing, may kill rabbits on their properties at any time in any part of the state, but rabbits so killed may not be transported or sold during the closed season (Calif. Administrative Code, Title 14, Sec. 308).

\section{Rabbit Control}

Rabbits are not difficult to control on 
small areas but present greater difficulty on large ranches. The methods used are: (1) exclusion, (2) shooting, (3) repellents, (4) trapping, (5) poisoning, and (6) encouragement of natural enemies.

Exclusion. A fence of mesh not greater than $1 \frac{1 / 2}{2}$ inches, buried to a depth of 6 inches in the soil and carried 24 to 36 inches above ground, will exclude all rabbits if it is patrolled at intervals to see that neither rabbits nor squirrels have dug passages under the buried portion. Such a fence, if constructed of poultry netting (although a heavier-mesh fence is better) and combined with barbed wire above, will often serve as a stock fence for horses and cattle. Sheep and hogs, however, are apt to damage a light wire fence, and hogs especially may root at the base of such a fence and so destroy its effectiveness. Neither jack rabbits nor cottontails will ordinarily jump over a 24-inch fence. But a jack rabbit when pursued by a dog may do so, particularly if the fence does not have closely spaced barbed wires above. Such a protective fence must, of course, be provided with tight-fitting gates and with sills or other means for making sure that rabbits cannot dig below the bottom rails of gates (fig. 25). The gates must be kept closed except when vehicles or persons are passing through.

Small spring-closing gates are useful in many places. A fence for exclusion is best for small flower or vegetable gardens, especially those adjoining large areas of pasturage, grain, alfalfa, or wild land. Any high-priced crop such as a small field of seed stock warrants the type of fencing here described. If such a fence is constructed there will be almost no

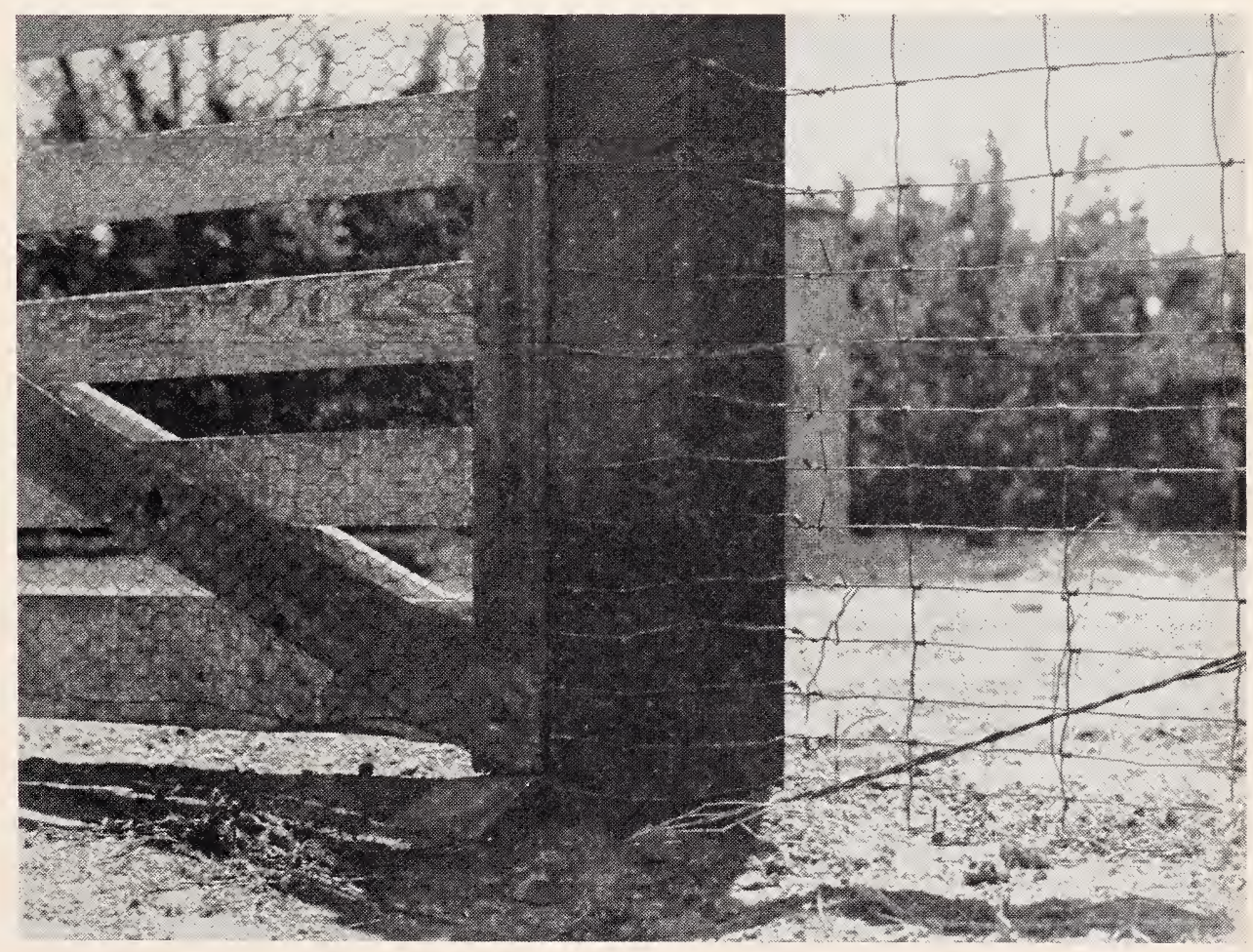

Fig. 25. Rabbit-proof fence and gate. Bottom of fence wire is buried 6 inches or more and lower meshes should not be more than $1 \frac{1}{2}$ inches apart. Gate is covered with 1 -inch poultry netting and bottom of gate must be within $1 \frac{112}{2}$ to 2 inches of the ground. 
damage by rabbits. When a small plot of ground needs to be enclosed for only a few months, light stakes may be used to support the wire, the bottom of which is buried in a furrow; then, after the crop has been harvested, the wire and stakes may be removed to permit the use of cultivating machinery.

Generally it is impractical to build rabbit-proof fencing around large acreages of farmland. The large rectangular mesh used as the lower part of a stock fence, where sheep or hogs are being pastured, has openings of a size that permits the passage of rabbits. Fencing for large areas with wire of strength adequate to restrain livestock and of mesh sufficiently small to exclude rabbits will cost upwards of $\$ 1.00$ per rod for the wire alone.

Over many years, farmers in California have used individual mechanical protectors to guard the trunks of young orchard trees against damage by rabbits. Earlier, thin slabs of yucca and other veneer materials were employed. Ordinary sacking has been tied around trees with effective results. Poultry netting of l-inch mesh, 20 -gauge galvanized wire, 18 to 24 inches in width, cut into strips 12 to 18 inches long and formed into cylinders around young trees, is a common means of protection. Such cylinders should be braced so that rabbits cannot press them against the trees and gnaw at the bark between the wire meshes. A fine-mesh wire or hardware cloth would also protect against meadow mice, especially if pressed down into the ground at the lower edge.

Shooting. Rabbits may be controlled by shooting. They feed mainly in the early morning, late afternoon, and dusk of evening, when a gun is most effective; but they may feed also at night, so that this method is not entirely successful. Ranchers troubled by numbers of cottontails may obtain some relief by inviting sportsmen to hunt over their lands during the open season. On certain ranches spring hunting of jack rabbits is promoted; the hunter thereby obtains some sport at a season when other game cannot be shot, and the rancher some reduction of jack rabbits. Such hunting, however, will seldom clear a ranch of the animals. Reduction of jack rabbits in the spring is of especial benefit in limiting the number of young which might otherwise be produced. Jack rabbits have been hunted for market use, and this aids in reducing their numbers, but there is some danger of contracting the disease tularemia when dressing wild rabbits. Any person skinning wild rabbits for fur or food is advised to wear rubber gloves.

Repellents. Various materials have been applied to bark and twigs of trees and vines in efforts to protect them from rabbits. Whitewash containing a good adhesive has some value, and also protects the bark against sunburn. In Idaho a strychnine-poisoned whitewash (formula 8) has protected young orchards, but it should not be applied where domestic animals are present. A solution of commercial resin in denatured ethyl alcohol (8 pounds per gallon) gave protection against gray rabbits in England. Sulfurized linseed oil (made by mixing powdered sulfur in heated linseed oil) has been effective in some cases, but in other trials has burned the bark and killed trees in some California orchards-thus it cannot be recommended. Some growers have avoided bark damage but gained protection by dipping laths in sulfurized oil and driving them in a circle around the trees. Fresh blood and some trade products sold as repellents have been tried, but results are irregular or unsatisfactory.

Trapping. The larger metal live traps recommended for taking tree squirrels (p. 36) will catch cottontails or brush rabbits injuring home gardens or orchards. The animals can be released at a distance of at least several miles and probably will not return. In Kansas a permanent rabbit trap has been used. It is made of a 4-foot length of 6-inch drain or sewer tile leading into a vertical $12 \times$ 
6-inch tee of tile having a heavy cover. Preferably the trap is placed in a natural setting amid brush and stones.

Poisoning. In areas where ranches are scattered and the human population is sparse, poison has been used to reduce jack rabbits. However, it must not be employed against cottontails or brush rabbits, which are classed as game.

The bait may be any food relished by jack rabbits-fresh alfalfa leaves and stems, moistened cotton stems, grain heads, oats, or rolled barley. Strychnine ( 5 ounces per 100 pounds of bait) is the principal poison, often combined with ordinary table salt, which is attractive to rabbits. For damp baits, the powdered poison (and salt) is dusted on, turning the bait repeatedly to obtain an even coating. Grain baits need an adhesive; formula 2 (p. 28) for ground squirrels bait has been used.

FORMULA 8

\section{Poison Wash to Protect Young Trees Against Rabbits}

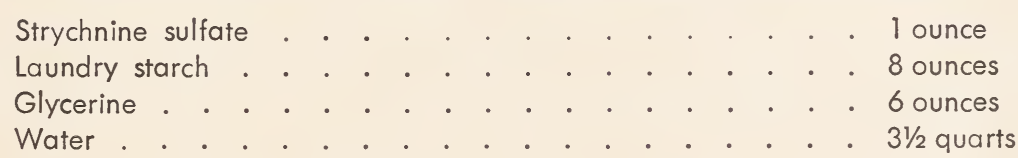

Prepare the laundry starch by mixing cold and then boiling in 1 pint of water. Dissolve the strychnine in the remaining water by boiling. Add the paste and glycerine. Cool and paint on trunks of trees. Do not admit domestic animals to orchards where this poison wash has been applied.

\section{See page 6-General Precautions with Poisons}

Before control by poison is attempted, clean prebait of several kinds should be spread in places where rabbits are doing damage to determine which kind will be taken most readily.

If poisoning is deemed necessary, the person responsible for the operations should make certain that all necessary precautions are taken to protect domestic animals, harmless wild animals, and human begins from danger. For example, on stock ranges where poisoning has to be employed because jack rabbits are so numerous as to reduce the pasturage, substantial fenced pens, about 12 feet square, excluding livestock but permitting jack rabbits to enter, have been used for the exposure of poisoned materials. Before poisoning, clean prebait should be offered to get the animals used to feeding at the site and to make certain that the poisoned bait material will be taken when provided later.

In the event that an owner or tenant is having difficulty with rabbits which cannot be solved by any of the methods indicated above, he should consult the agricultural commissioner or the farm advisor of his county for appropriate methods.

Encouraging natural enemies. The red-tailed hawk and golden eagle-birds protected by state law-both feed upon rabbits, and the gopher snake is known to capture small ones. These and other natural enemies that subsist on rabbits and rodents are valuable aids to the farms. 


\section{For more information}

Additional information on miscellaneous rodents and rabbits may be found in the following publications:

Beck, J. R. (editor)

1959. The Oregon meadow mouse irruption of 1957-1958. Corvallis, Oregon, Federal Cooperative Extension Service. 88 pp., illus. Ten articles by various authors on biological and economic aspects, control, and disease.

Ingles, L. G.

1941. Natural history observations on the Audubon cottontail. Jour. Mammalogy 22 : $227-50,2$ pls., 5 figs.

Lantz, D. E.

1924. Cottontail rabbits in relation to trees and farm crops. U. S. Dept. Agr. Farmers' Bul. 702: 1-14 (Revised).

Marsh, R. E., and L. F. Plesse

1960. Semipermanent anticoagulant baits. California State Dept. Agr. Bul. 49: 195-97, 4 figs.

Murray, K. F.

1965. Population changes during the 1957-1958 vole (Microtus) outbreak in California. Ecology 46: 163-71. 1 map.

Orr, R.T.

1940. The rabbits of California. California Academy of Sciences Occasional Papers 19: 1-277. 10 pls. 30 figs.

Storer, T.I.

1937. The muskrat as native and alien. Jour. Mammalogy 18:443-60. Also in: California Fish and Game 24: 159-75. 1938.

Twining, Howard, and A. L. Hensley

1943. The distribution of muskrats in California. California Fish and Game 29: 64-78.

In order that the information in our publications may be more intelligible it is sometimes necessary to use trade names of products or equipment rather than complicated descriptive or chemical identification. In so doing it is unavoidable in some cases that similar products which are on the market under other trade names may not be cited. No endorsement of named products is intended nor is criticism implied of similar products which are not mentioned.

Co-operative Extension work in Agriculture and Ilome Economics, College of Agriculture, University of California, and United States Department of Agriculture co-operating. Distributed in furtherance of the Acts of Congress of Nlay 8, and June 30, 1914. George B. Nlcorn, Director, California Agricultural Extension Service. 


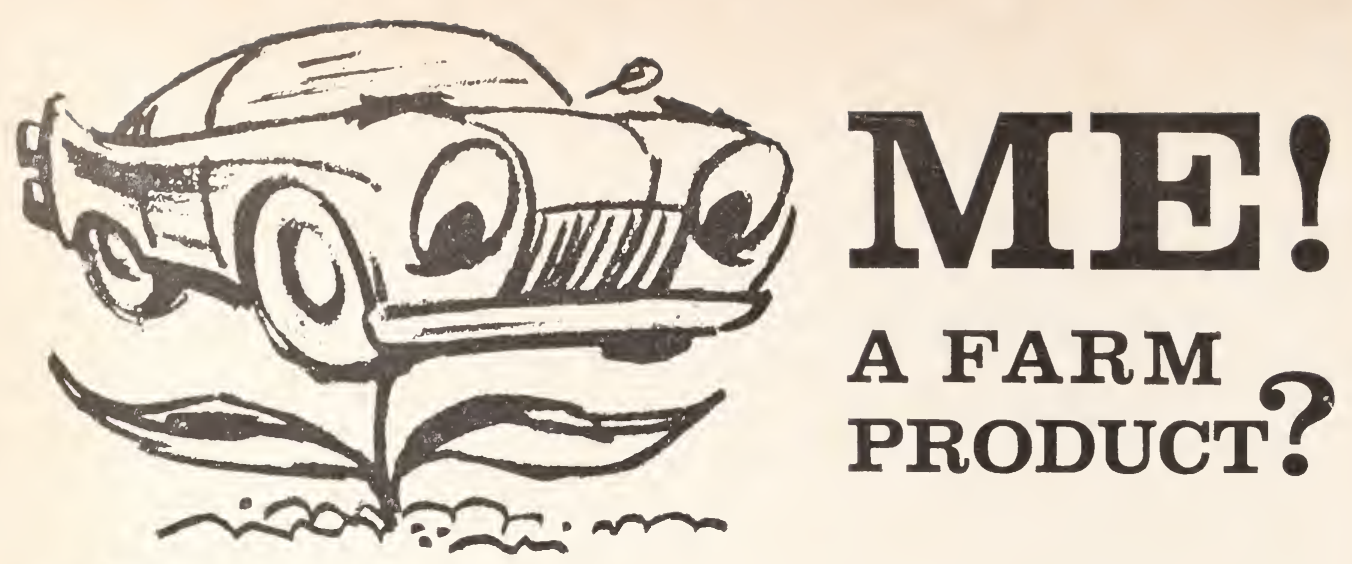

\section{A FARM PRODUCT?}

Well, not exactly-you can't grow automobiles on farms, but farm products are essential in manufacturing them. Consider the annual agricultural needs of just one major automobile company.

900,000 bushels of corn
736,000 bushels of flax-
seed
74,000 bales of cotton

or, in terms of approximate acreage:

15,000 acres of corn
80,000 acres of flax
78,000 acres of cotton

During the same period this company used products derived from 364,000 sheep and 36,000 cattle-plus many other items such as hog bristles and beeswax. In all, produce equivalent to the output of 1,000 good-sized farms is needed yearly. No wonder a top executive in the automotive industry has said: "Our plants, here and throughout the world, would have to close their doors in a few days if their flow of agricultural materials were to stop."

Supplying America's countless industries-and feeding the nation bountifully-makes agriculture America's biggest and perhaps most important business. That is one reason why anything which affects agriculture affects everybody. 